Article

\title{
Sand Ridges on Rocky Coastal Platforms as Markers of Tsunami Impact: A Multi-Disciplinary Analysis along the Ionian Coast of Southern Apulia (Italy)
}

\author{
Paolo Sansò ${ }^{1, *(1)}$, Lucio Calcagnile ${ }^{2}$, Paola Fago ${ }^{3,4}{ }^{\text {, Sara Mazzotta }}{ }^{5}$, Sergio Negri ${ }^{1}$, \\ Gianluca Quarta $^{2}$, Claudia Romagnoli ${ }^{5} \mathbb{D}$, Andrea Vitale ${ }^{1}$ and Giuseppe Mastronuzzi ${ }^{4}$ \\ 1 Dipartimento di Scienze e Tecnologie Biologiche e Ambientali, Università del Salento, Complesso Ecotekne, \\ 73100 Lecce, Italy; sergio.negri@unisalento.it (S.N.); vitaleandrea@inwind.it (A.V.) \\ 2 CEDAD (Centro di Fisica Applicata, Datazione e Diagnostica), Dipartimento di Matematica e Fisica "Ennio \\ de Giorgi", Università del Salento, Via per Arnesano, 73100 Lecce, Italy; lucio.calcagnile@unisalento.it (L.C.); \\ gianluca.quarta@unisalento.it(G.Q.) \\ 3 Polo Scientifico e Tecnologico Magna Grecia, Università degli Studi di Bari, Via Alcide de Gasperi, \\ 74123 Taranto, Italy; paola.fago@gmail.com \\ 4 Dipartimento di Scienze della Terra e Geoambientali, Università di Bari, Via E. Orabona 4, 70125 Bari, Italy; \\ giuseppe.mastronuzzi@uniba.it \\ 5 Dipartimento di Scienze Biologiche, Geologiche e Ambientali, Università di Bologna, P.za di Porta San \\ Donato 1, 40126 Bologna, Italy; saramaz92@gmail.com(S.M.); claudia.romagnoli@unibo.it(C.R.) \\ * Correspondence: paolo.sanso@unisalento.it
}

Received: 28 April 2020; Accepted: 20 May 2020; Published: 27 May 2020

\begin{abstract}
Along the Ionian coast of Southern Apulia, a sand ridge has been detected at the inner border of a wide, low-elevated rocky platform. A multi-disciplinary analysis was carried out to define the main geomorphological and sedimentological features of this dune-like coastal deposit, to clarify its nature as well as to obtain chronological constraints for its development. The geomorphological survey reveals that the sand ridge is about $40-60 \mathrm{~m}$ wide, reaching a maximum elevation of $3.9 \mathrm{~m}$ above m.s.l., whereas its thickness can be estimated between 1.0 and $2.8 \mathrm{~m}$. The sand ridge is in some places associated with large-size boulders. Grain size analysis shows that it is made up of poorly sorted coarse-medium sands with a gravelly fraction, without significant sedimentary structures, as confirmed by Ground Penetrating Radar survey. The micro and macro-faunal assemblage sampled in the sand ridge can be related to shallow-water environments with Posidonia oceanica meadows occurring offshore. The development of the studied sand ridge can be ascribed to a tsunami event able to mix up very coarse bioclastic sands placed at submerged platforms, storm beach deposits covering the low-elevated coastal platform in patches, and possibly older tsunami deposits. Accelerator Mass Spectometry radiocarbon age determinations on mollusc shells sampled from the sand ridge span from 929-1168 AD to 1707-1950 AD and cluster around the 18th-19th centuries, suggesting a possible association with a recent tsunami event. Data reported in the Euro-Mediterranean Tsunami Catalogue would indicate as the most likely event that one of the 25th April 1836, produced by a strong earthquake with its epicenter near Rossano village, on the Ionian coast of the Calabria region.
\end{abstract}

Keywords: tsunami deposit; sand ridge; southern Apulia; Italy

\section{Introduction}

The interest of the scientific community in tsunami studies has significantly increased in the last two decades, especially in terms of hazard assessment and risk reduction. The occurrence of the catastrophic Indonesian (2004) and Tohoku (2011) tsunamis highlighted the necessity of detecting 
coastal regions prone to tsunamis, especially in the Mediterranean Basin, where for a long time tsunami hazard has been underestimated, notwithstanding that all types of possible sources (earthquakes, volcanic eruptions and subaerial as well as submarine landslides) are active. In addition to this, recent research has pointed out the occurrence of non-seismic sea level oscillations at tsunami timescales (NSLOTTs); these are generated by the resonant transfer of energy from a travelling atmospheric disturbance to the ocean through the Proudman resonance phenomenon [1]. NSLOTTs should be also taken into account since in some extreme cases, referred to as "meteorological tsunamis" or "meteotsunamis", they are capable of producing damage or a significant impact on a coastal area [1].

The Italian peninsula, in particular, due to its particular geodynamic context and geographical position, appears vulnerable to tsunamis generated in different areas of the Mediterranean Sea, as testified by recent historical research, i.e., [2], and geophysical models, i.e., [3]. However, in the last two decades, geomorphological and sedimentological field surveys have been carried out [4] aiming at: (i) recognizing deposits and landforms produced by the impact of tsunamis, and (ii) reconstructing past events sequences, since a critical analysis of field evidence may contribute to the assessment of potential future coastal hazard and risk scenarios. Some of these studies focused on Southern Apulia (Italy), a narrow peninsula stretching between the Adriatic and the Ionian Sea, which retains at several sites the effects of devastating tsunamis which struck its coast during historical times.

Southern Apulia belongs to the emerged part of the Adria plate, a lithospheric block formerly connected to north Africa that drifted away from it during the Mesozoic. It constitutes the foreland of the east-verging Southern Apenninic Chain to the west and of the west-verging Dinaric-Albanian-Hellenic orogens to the East [5,6] (Figure 1a). The Bradanic foredeep prolongs offshore in a buried thrust front crossing the middle of the Ionian Sea (Figure 1b). The Adria Plate is composed of two dissimilar crustal sectors, as reflected in the bathymetry (Figure 1b). Whereas the shallow Adriatic Sea region to the northeast is floored by continental crust, the deep Ionian Sea to the southwest is thought to lie upon thinned continental or oceanic crust related to stretching and rifting [6]. The margin between the two crustal domains lies beneath the Ionian Sea and projects to the northwest in Calabria, underneath the accretionary wedge [6] (Figure 1a,b).

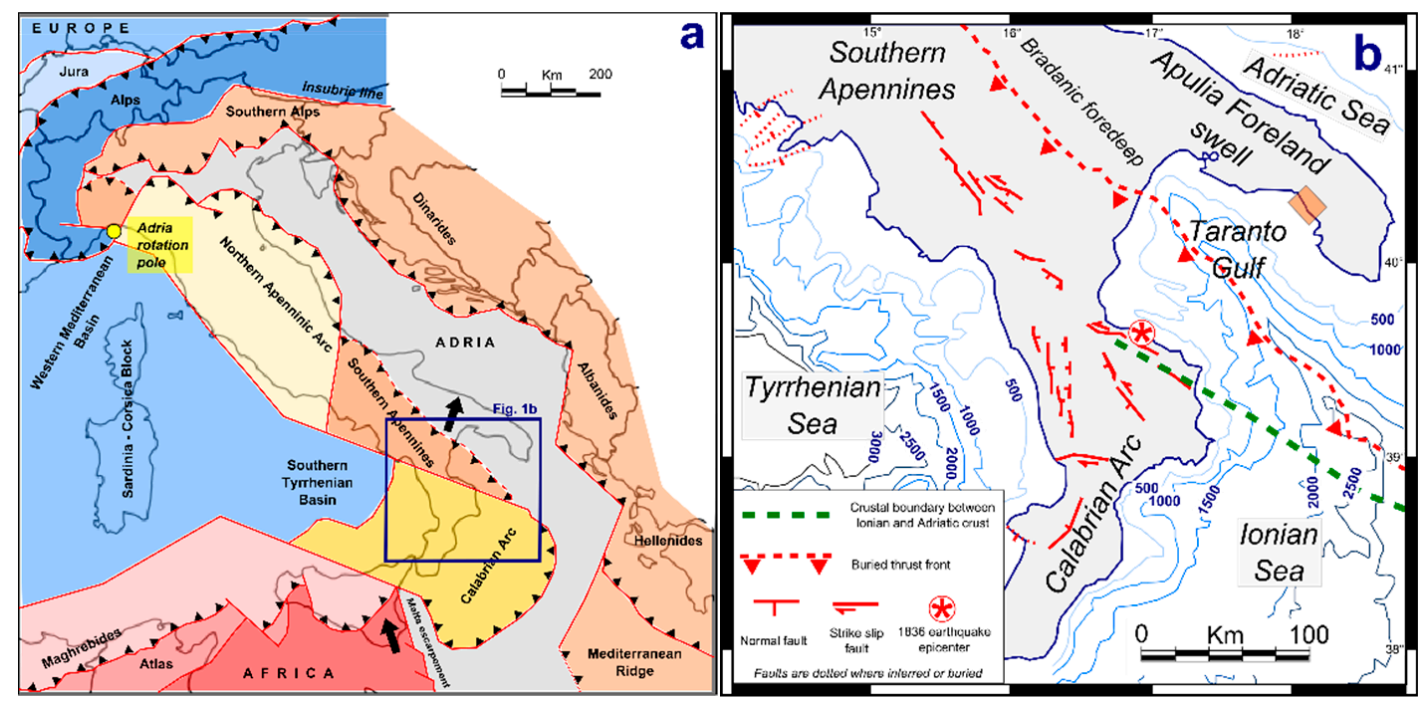

Figure 1. (a) (left): Geodynamic sketch of the Adria plate and surrounding areas (from [5]; mod.). Black arrows indicate plate motion; the blue box marks the area mapped in Figure 1b. (b) (right): Regional tectonic setting of Southern Italy (from [6]; mod.); the main active faults on land and offshore and the 1836 Rossano earthquake epicenter are shown. The orange box indicates the position of the studied coastal area. 
Southern Apulia is one of the Italian coastal regions more often exposed to tsunami hazard since the surrounding seas are affected by several seismic structures able to generate strong tsunamis. In particular, to the east, the fronts of the Dinarides, Albanides, and Hellenides are seismologically and geodetically active, whereas, to the west, the coastal sector of the Apennines abutting the Ionian Sea and the Calabrian Arc has experienced vigorous uplift ( $\sim \mathrm{mm} / \mathrm{a}$ and locally more) since the middle Pleistocene, as manifested by staircases of raised paleoshorelines, whose deformed profiles embed both a long- and a short-wavelength component, the latter reflecting local folding and faulting [6].

Thus, it is not surprising that geomorphological research carried out during the last twenty years along the coasts of southern Apulia (Italy) has detected the effects of tsunami impacts which occurred during the past centuries [7-12]. They are mainly constituted by large-size boulders which can be found isolated, arranged in lines of imbricated elements or in large accumulations. Boulders were detached from sub-tidal or supra-tidal areas and transported for tens of meters inland to be deposited on low-elevated coastal platforms. Hydrodynamic computations based on boulders' size and position indicate that sea storm waves that can be presently generated in the Ionian and Adriatic Seas do not have enough power to produce the carving and transport of the detected boulders, so that boulder accumulations suggest the impact of a tsunami that hit the southern Apulia coast during the last centuries [13].

However, large-size boulders are not the only possible tsunami records recognizable along Southern Apulia. A coastal tract stretching along its Ionian side from Porto Cesareo to Nardò for about $11 \mathrm{~km}$ (Figure 2), is, in fact, marked by the occurrence of a ridge made of unconsolidated clastic deposits that border landward a wide, bare, low-elevated rocky platform (Figure 3). At first glance, it may resemble a low dune belt (as suggested by [14]), but a deeper analysis reveals peculiar sedimentological and paleo-ecological features.

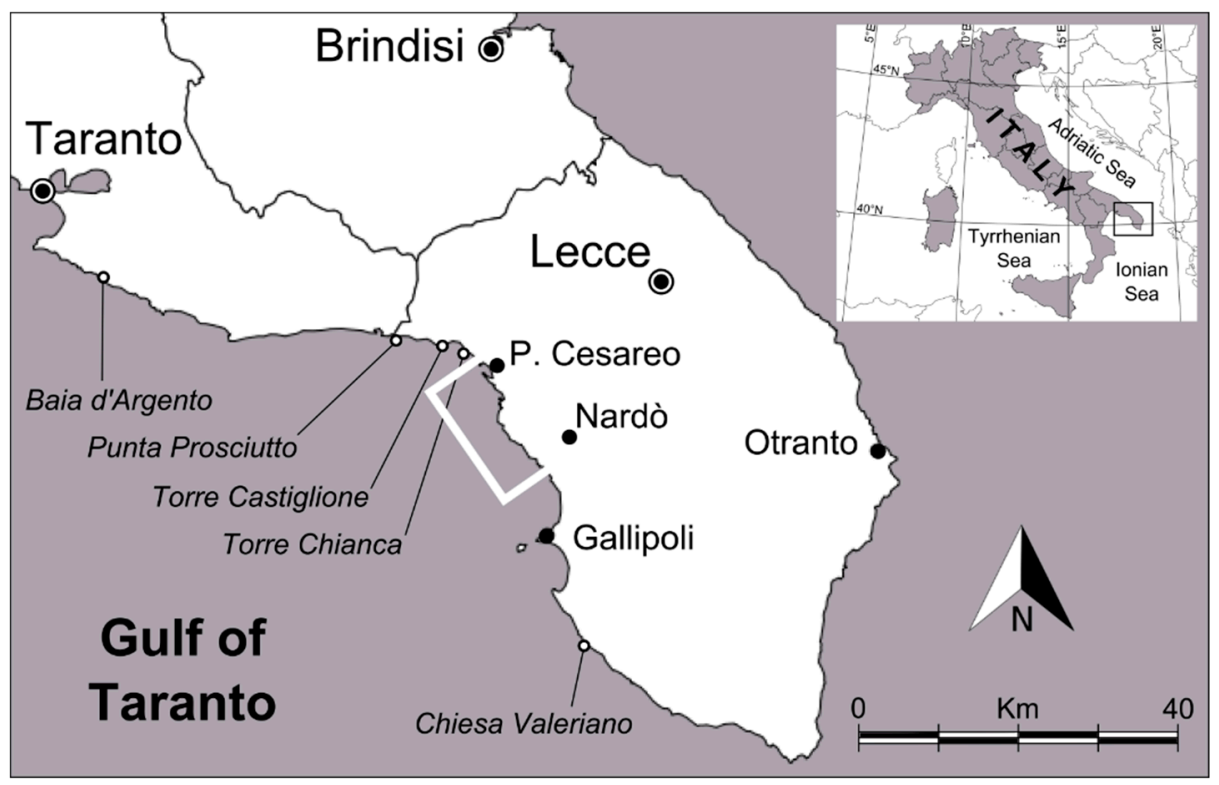

Figure 2. Geographical position of the studied area and main localities cited in the text.

A multi-disciplinary study involving geomorphological, sedimentological, geophysical and geochronological analyses has been carried out aiming to determine the nature of this deposit as well as to obtain some chronological constraints for its development. 


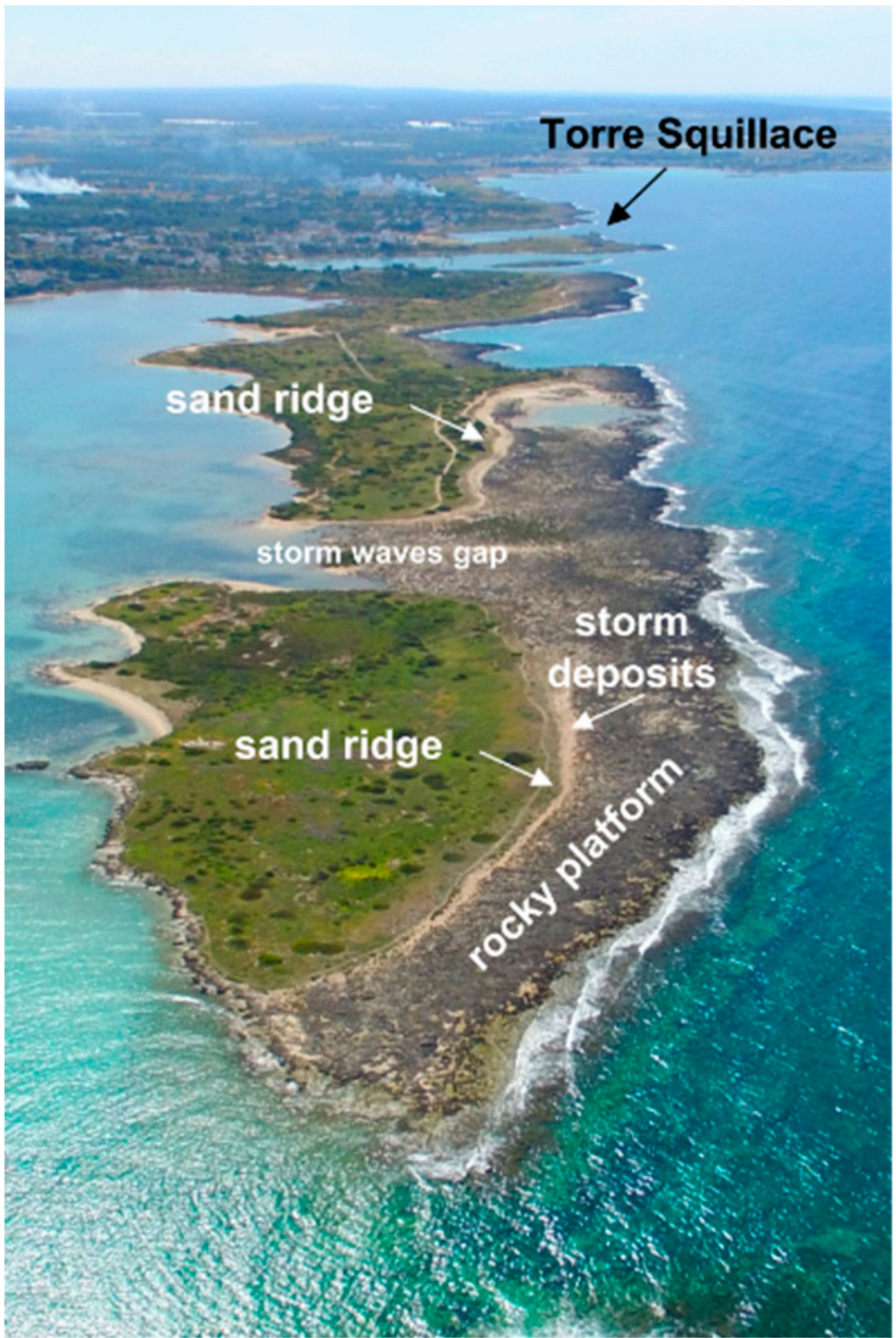

Figure 3. An aerial view of the La Strea site (Porto Cesareo municipality). The low-elevated rocky platform backed by the studied sand ridge is well visible. The surface of the rocky platform is actively washed by storm waves that produce an erosive gap through the sand ridge.

\section{Geological and Geomorphological Outlines}

The Ionian side of Southern Apulia is marked by a coastal landscape showing a sequence of marine terraces arranged in a flight of morphological steps developed in the NNW-SSE direction (Figure 4). In detail, six orders of marine terraces can be recognized between $46 \mathrm{~m}$ and $1 \mathrm{~m}$ of altitude. They formed because of the superimposition of mid-late Pleistocene glacio-eustatic sea level change and regional uplift. Southern Apulia, in fact, was affected by rapid uplift during the Middle Pleistocene followed by tectonic stability during the last $330 \mathrm{ka}[15,16]$.

The lowest marine terrace (V-VI orders in Figure 4) stretches from about $3 \mathrm{~m}$ above m.s.l. to a few decimetres below m.s.l.; it is a polycyclic rocky platform (Figure 3) formed during the main interglacial high-stands, which occurred during the last 330 ka because of the relative tectonic stability of the area. In fact, it is cut on yellowish algal calcarenites of age greater than $300 \mathrm{Ka} \mathrm{BP} \mathrm{[17],} \mathrm{but} \mathrm{close} \mathrm{to} \mathrm{the}$ 
coastline a younger, thin marine calcarenitic cover can be recognized (VI order in Figure 4); on the basis of regional data, this can be referred to the Last Interglacial Period (Marine Isotope Stage 5.5) [15,16].

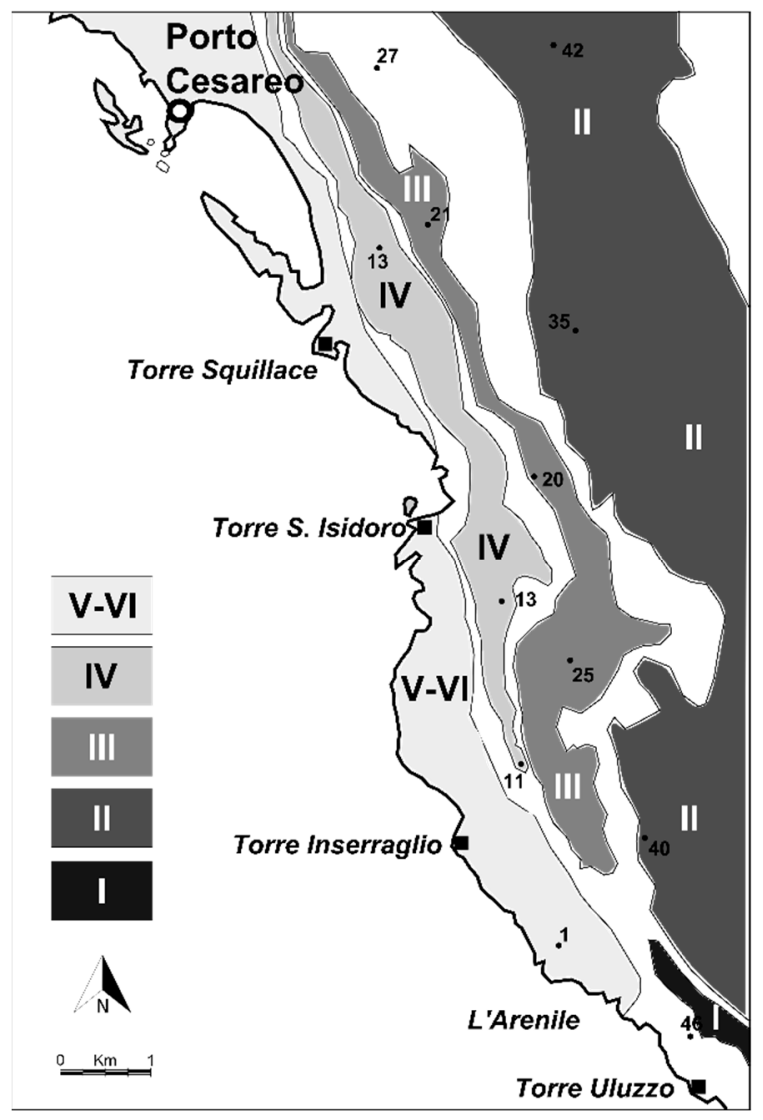

Figure 4. The coastal area stretching from Porto Cesareo to the L'Arenile site is marked by a staircase of marine terraces stretching between $40 \mathrm{~m}$ of altitude and mean sea level. The lower terrace is a polycyclic, rocky coastal platform shaped during the last $330 \mathrm{ka}$ and placed between $3 \mathrm{~m}$ above m.s.l. and $1 \mathrm{~m}$ below m.s.l.

\section{Materials and Methods}

The research integrates data coming from different approaches, including geomorphology, sedimentology, geophysics and geochronology.

A geomorphological survey of the coastal area between Porto Cesareo village and the L'Arenile site was integrated by the reconstruction of transverse profiles of the coast by means of a topographic total station (Figure 5). Profiles S2 and S5 were integrated by scuba surveys of geomorphological features performed by two divers with ARA equipment and digital acquisition of depth using logs from a digital portable depth gauge; present-day sediment covering the rocky sea bottom in patches was also sampled at Profile S2 (Sample A4).

The sand ridge was mapped through GIS application, and samples were collected using a manual corer (B1 to B3). Present-day coastal deposits have been also sampled for comparison purposes (Samples A1 to A4 in Figure 5). Sample B5 was collected at a trench, about $2 \mathrm{~m}$ deep, dug at the L'Arenile site by means of a mini-excavator.

Grain size analyses were performed at the BIGEA Department of Bologna University by ASTM (America Society for Testing and Materials) sieves from $2 \mathrm{~mm}$ to $0.063 \mathrm{~mm}$ at 1 phi intervals. Data were managed using the software GRADISTAT [18], which allows basic grain size statistics [19] to be obtained. Lithologic and morphoscopic analyses of samples were also performed by binocular microscope to determine the main characteristics of grains and faunal assemblages. 


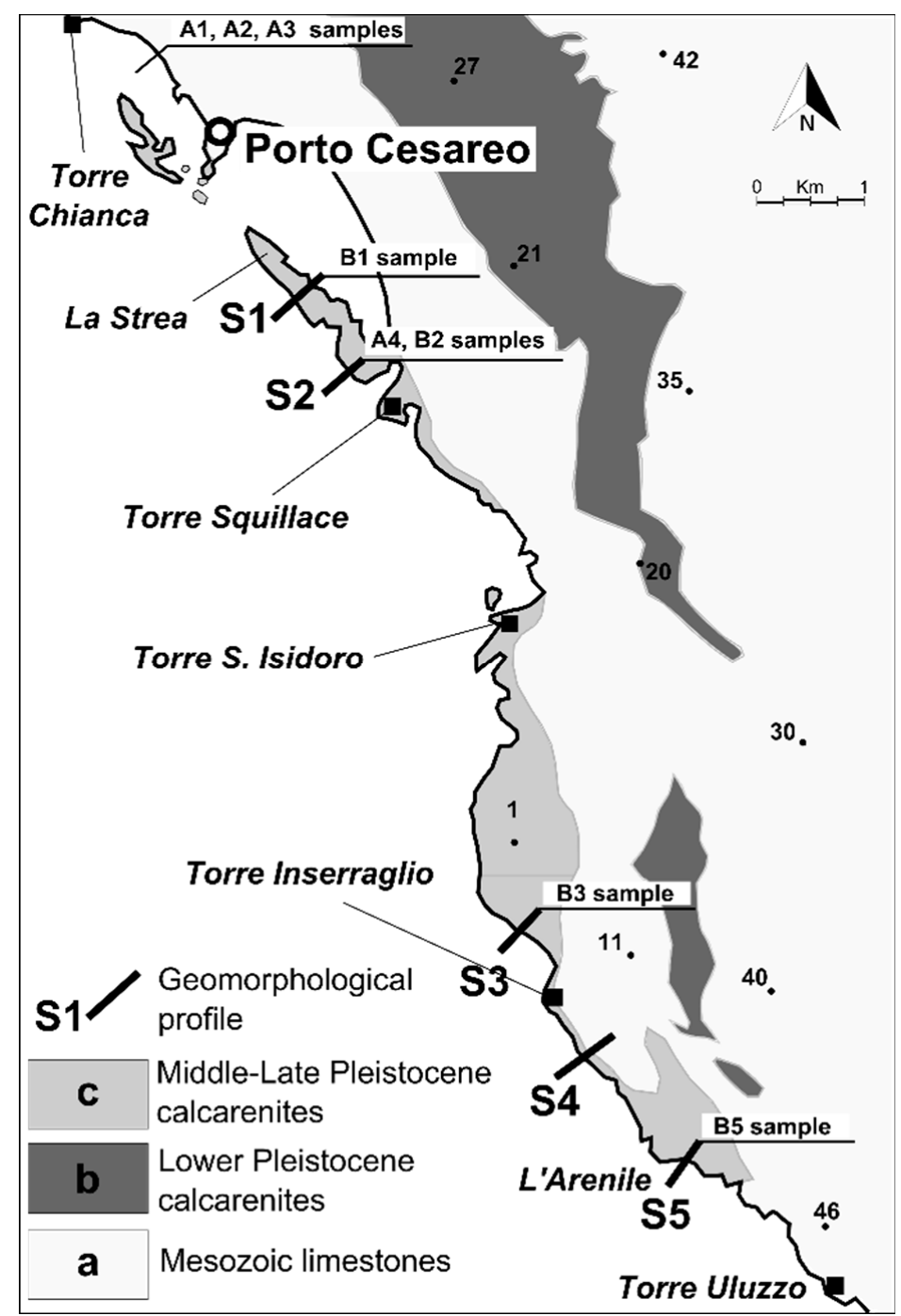

Figure 5. Location of geomorphological profiles and samples, superimposed on the schematic geological map of the studied area.

A Ground Penetrating Radar survey was carried out along two profiles by means of a Ground Penetrating Radar System 3000 (GSSI), adopting antenna frequencies of $900 \mathrm{MHz}, 500 \mathrm{MHz}$ and 400 MHz. Ground Penetrating Radar (GPR) is a non-invasive geophysical method based on electromagnetic wave (EM) propagation, which is sensitive to electromagnetic parameters, in particular to dielectric permittivity contrasts in the shallow subsurface. Vertical resolution of a radar reflection profile increases as frequency increases as well [20-22]; this has important implications for its sedimentological interpretation, as it will determine the scale of sedimentary structure that can be observed [23]. GPR, in fact, can easily detect the internal structure of detritic deposits due to the occurrence of stratification or lamination as well as to grain size change (see, for instance, [24]).

GPR survey 1 was carried out along Profile S1 (La Strea site) and GPR survey 2 along Profile S5 (L'Arenile site) to thoroughly investigate the ridge deposit; constant velocities of 0.12 and $0.13 \mathrm{~m} / \mathrm{ns}$, respectively, were assumed for the topographic correction.

AMS (Accelerator Mass Spectrometry) age determinations were performed by radiocarbon dating at the Centre for Applied Physics, Dating and Diagnostics, Department of Mathematics and Physics, University of Salento [25]. The results of the AMS analyses were calibrated using the software OxCal Ver. 3.10 based on marine data [26] and adopting a $\Delta R$ value of $58 \pm 15$, which is assumed to be the mean value for the Mediterranean Sea. 


\section{Results}

\subsection{Geomorphological and Sedimentological Characteristics of the Coastal Sand Ridge}

The studied coastal tract is marked in several places by a sand ridge running parallel to the coastline, which resembles in shape and position an aeolian dune belt [14]. It is placed at the inner border of a low-elevated, bare rocky coastal platform, up to about $100 \mathrm{~m}$ wide, representing the outer part of the V and VI marine terrace orders (Figure 3). This gently slopes seaward to about $1 \mathrm{~m}$ below m.s.l. and is diffusely affected by solution features (potholes, pinnacles, alveolar weathering, and so on). Large-size boulders rest on the surface's platform in several sites; they are sparse or arranged in lines of imbricated elements as at the Torre Inserraglio site (Figure 6).

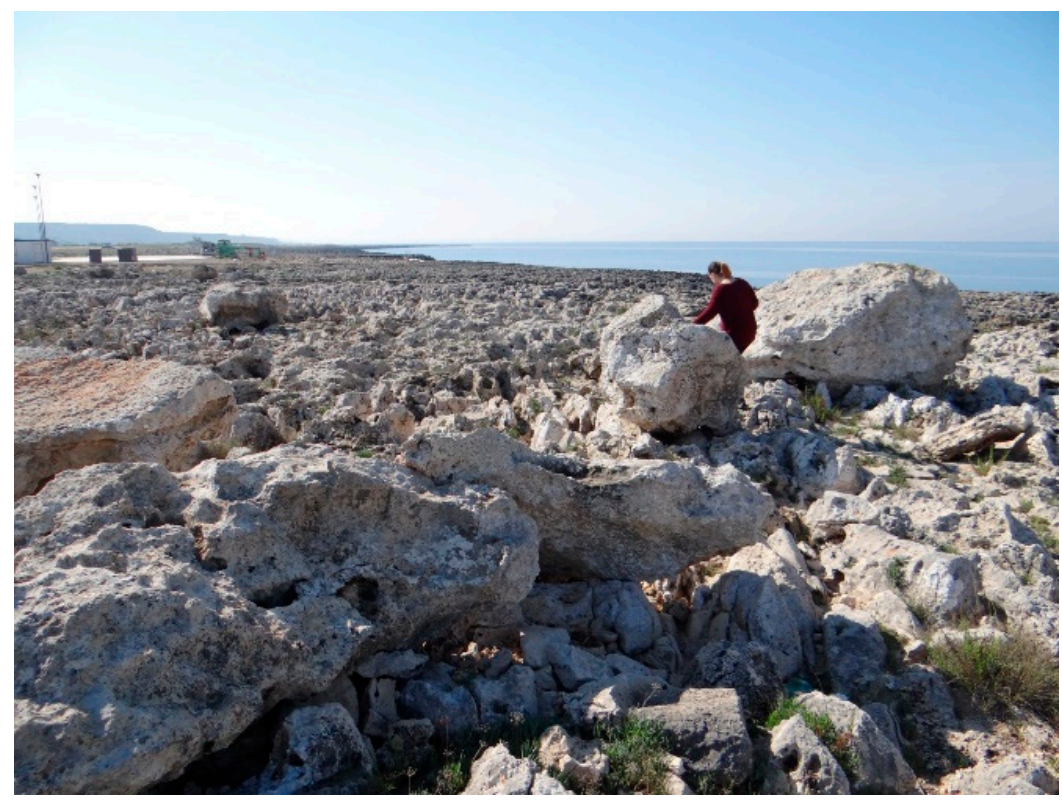

Figure 6. A view of large-size imbricated boulders resting on the low-elevated rocky platform occurring at Torre dell'Inserraglio site, along Profile S3.

A submerged cliff constitutes the seaward margin of the rocky coastal platform; at the cliff's foot, a submerged coastal platform can be detected at about 4-11 $\mathrm{m}$ of depth, covered in patches by coarse bioclastic sediment. At the back of the coastal sand ridge, the rocky platform surface is covered by a continuous dark red soil cover colonized by herbs and shrubs.

The surveyed sand ridge shows several unusual features which suggest the need for a detailed, multidisciplinary analysis of this landform and related deposits.

\section{(a) Morphological Features}

The main morphological features of the investigated coastal sand ridge were represented through five transverse profiles (Figure 7). Profiles S1, S3 and S4 stretch up to $200 \mathrm{~m}$ starting from the coastline towards the backshore, whereas Profiles S2 and S5 are longer, since they comprise a submerged tract (Profile S2, La Strea site and Profile S5, L'Arenile site).

The collected data show that the sand ridge top is about $80 \mathrm{~m}$ far from the coastline, except at Profile S1, where a distance of about $105 \mathrm{~m}$ has been measured. The ridge is about $40-60 \mathrm{~m}$ wide with the top reaching an elevation between $1.4 \mathrm{~m}$ (Profile S4) and $3.9 \mathrm{~m}$ (Profile S1) above m.s.l.; its thickness can be estimated between 1.0 and $2.8 \mathrm{~m}$. The ridge has an asymmetrical profile with a steeper seaward slope (9-14\%), whose foot is eroded by waves during extreme sea storms so that a decametric level of dark reddish soil interposed between the bedrock and the sand ridge (Figure 7) locally crops out. In some places, storm waves reworked the sand ridge deposits forming a low storm berm at the 
ridge's foot (Figure 8). At the La Strea site, storm waves shaped an erosive gap through the sand ridge (Figure 3). The landward slope is gentler (5-10\%) and generally covered by vegetation (Figure 8 ).

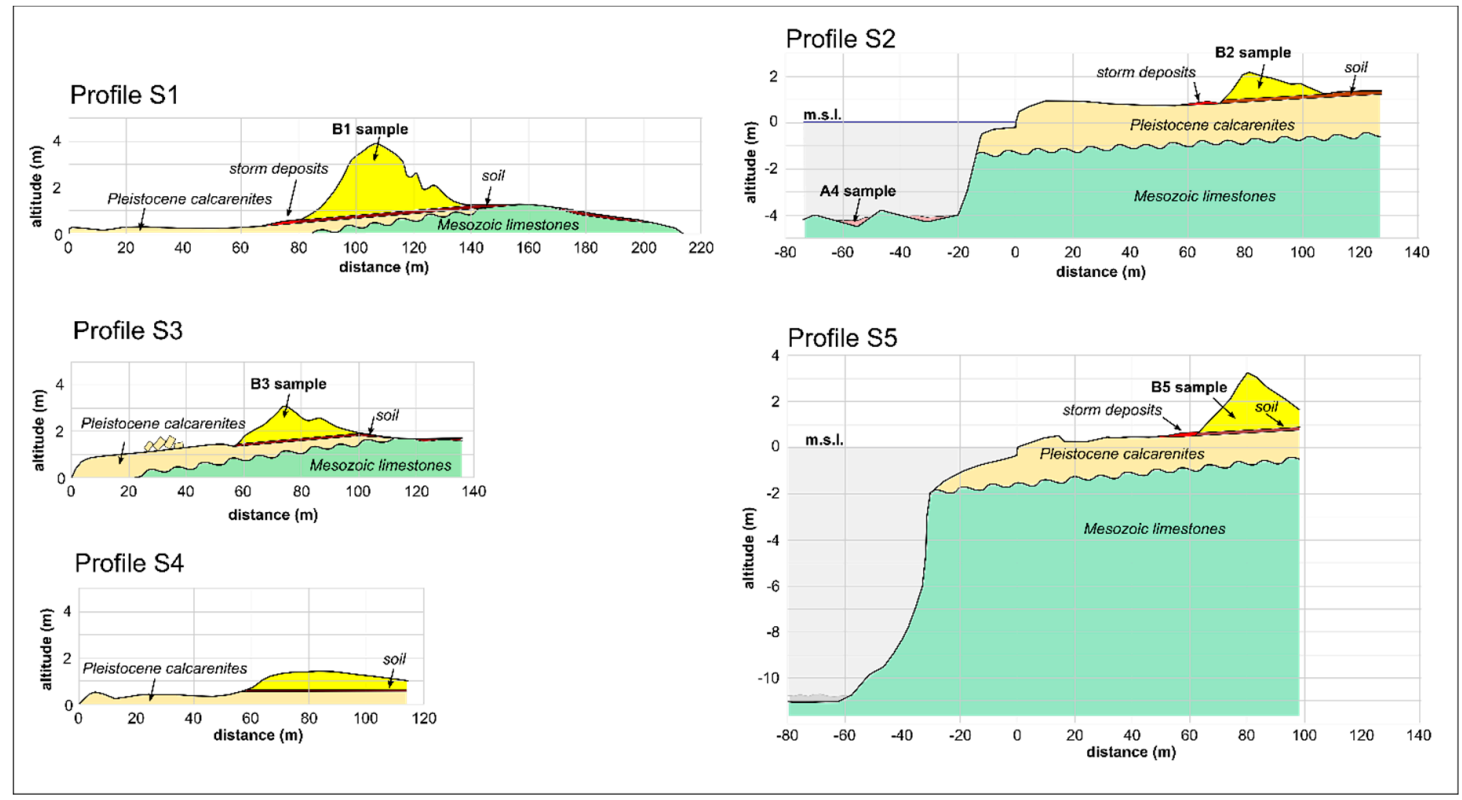

Figure 7. Geomorphological profiles carried out at five sites along the studied coast (location in Figure 5). Horizontal and vertical scales are the same for all profiles. The yellow area marks out the sand ridge deposits.
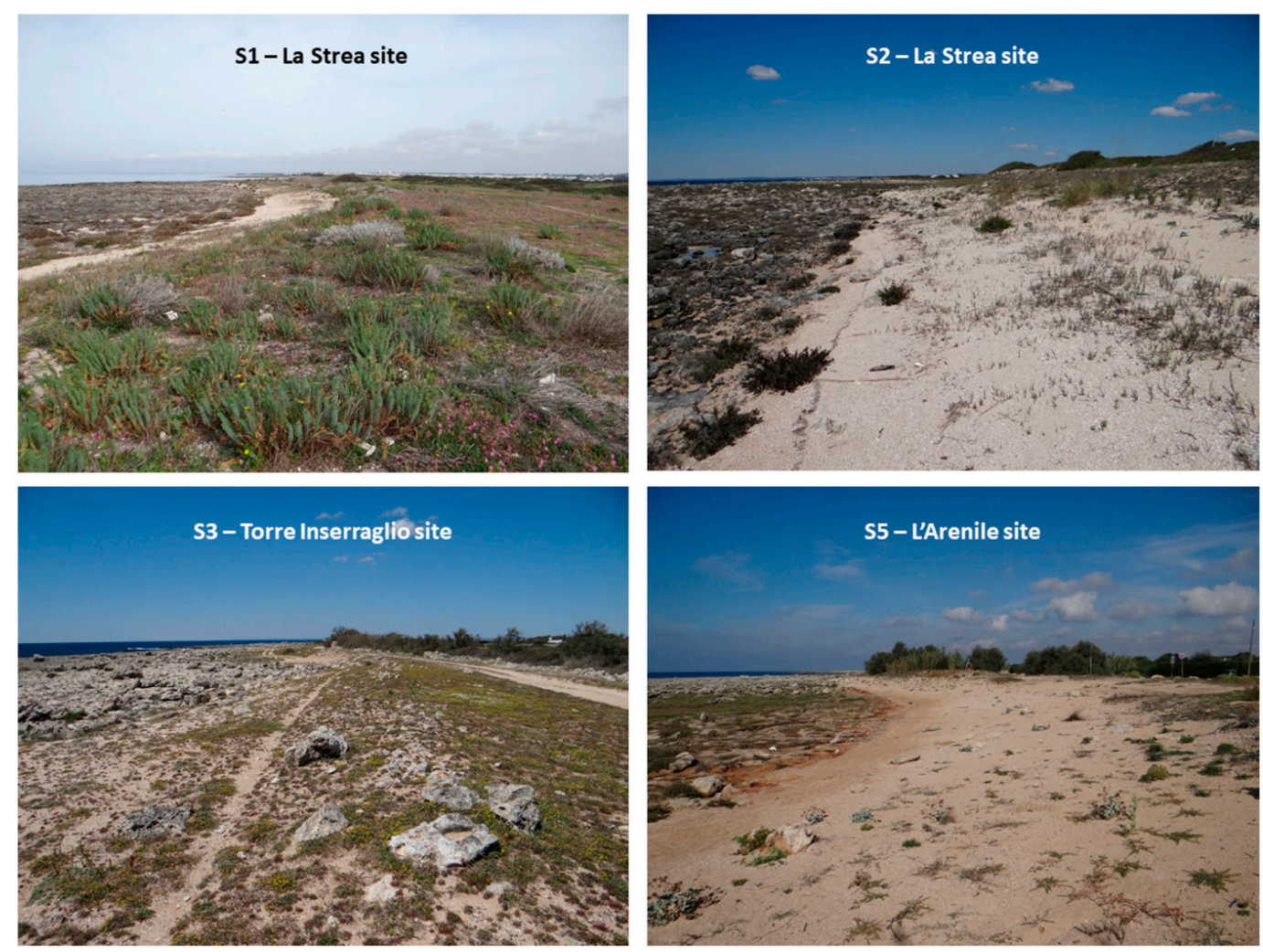

Figure 8. Views of the coastal sand ridge at different sites. Sea is at left (west side), land at right (east side). The sand ridge surface is vegetated except at the foot of its seaward slope, reached by storm waves responsible for the deposition of a low storm berm. 


\section{(b) Sedimentological Characteristics}

To compare present beach and dune deposits with those of the coastal sand ridge, grain size and morphoscopic analyses were also carried out on three samples of the present beach (Samples A1, A2, A3) collected at Torre Chianca, close to the northern border of the studied area (Figure 5), and on a further sample of the biodetritic cover occurring in patches at the submerged platform in correspondence to La Strea site (Sample A4 in Profile S2, Figure 7) (Table 1).

Table 1. Grain size statistics of the present beach (A1-A4) and sand ridge (B1-B5) samples.

\begin{tabular}{|c|c|c|c|c|c|c|c|c|}
\hline Sample & $\begin{array}{c}\text { Long. E } \\
\text { (WGS84) }\end{array}$ & $\begin{array}{c}\text { Lat. N } \\
\text { (WGS 84) }\end{array}$ & $\begin{array}{l}\text { Alt. } \\
\text { (m) }\end{array}$ & Position & Mean & Sorting & Skewness & Kurtosis \\
\hline \multirow{2}{*}{ A1 } & \multirow{2}{*}{$40^{\circ} 16^{\prime} 22.47^{\prime \prime}$} & \multirow{2}{*}{$17^{\circ} 52^{\prime} 36.21^{\prime \prime}$} & \multirow{2}{*}{2.0} & \multirow{2}{*}{ dune } & 1.345 & 0.710 & -0.076 & 1.227 \\
\hline & & & & & medium sand & moderately sorted & symmetrical & leptokurtic \\
\hline \multirow[b]{2}{*}{ A2 } & \multirow[b]{2}{*}{$40^{\circ} 16^{\prime} 22.25^{\prime \prime}$} & \multirow[b]{2}{*}{$17^{\circ} 52^{\prime} 36.23^{\prime \prime}$} & \multirow[b]{2}{*}{1.0} & \multirow[b]{2}{*}{ backshore } & 1.345 & 0.658 & -0.103 & 1.281 \\
\hline & & & & & medium sand & moderately well sorted & $\begin{array}{l}\text { coarse } \\
\text { skewed }\end{array}$ & leptokurtic \\
\hline \multirow[b]{2}{*}{ A3 } & \multirow[b]{2}{*}{$40^{\circ} 16^{\prime} 22.00^{\prime \prime}$} & \multirow[b]{2}{*}{$17^{\circ} 52^{\prime} 36.25^{\prime \prime}$} & \multirow[b]{2}{*}{0.3} & \multirow[b]{2}{*}{ shoreface } & 1.069 & 0.642 & -0.141 & 0.755 \\
\hline & & & & & medium sand & moderately well sorted & $\begin{array}{l}\text { coarse } \\
\text { skewed }\end{array}$ & platykurtic \\
\hline \multirow{2}{*}{ A4 } & \multirow{2}{*}{$40^{\circ} 14^{\prime} 21.42^{\prime \prime}$} & \multirow{2}{*}{$17^{\circ} 54^{\prime} 09.82^{\prime \prime}$} & \multirow{2}{*}{-4.0} & \multirow{2}{*}{$\begin{array}{l}\text { submerged } \\
\text { beach }\end{array}$} & -0.199 & 0.864 & -0.086 & 1.348 \\
\hline & & & & & very coarse sand & moderately sorted & symmetrical & leptokurtic \\
\hline \multirow{2}{*}{ B1 } & \multirow{2}{*}{$40^{\circ} 14^{\prime} 42.28^{\prime \prime}$} & \multirow{2}{*}{$17^{\circ} 54^{\prime} 04.74^{\prime \prime}$} & \multirow{2}{*}{2.0} & \multirow{2}{*}{ sand ridge } & 1.145 & 0.840 & 0.090 & 0.871 \\
\hline & & & & & medium sand & moderately sorted & symmetrical & platykurtic \\
\hline \multirow[b]{2}{*}{ B2 } & \multirow[b]{2}{*}{$40^{\circ} 14^{\prime} 22.18^{\prime \prime}$} & \multirow[b]{2}{*}{$17^{\circ} 54^{\prime} 23.00^{\prime \prime}$} & \multirow[b]{2}{*}{1.6} & \multirow[b]{2}{*}{ sand ridge } & -0.148 & 1.430 & -0.173 & 1.178 \\
\hline & & & & & very coarse sand & poorly sorted & $\begin{array}{c}\text { coarse } \\
\text { skewed }\end{array}$ & leptokurtic \\
\hline \multirow[b]{2}{*}{ B3 } & \multirow[b]{2}{*}{$40^{\circ} 11^{\prime} 26.67^{\prime \prime}$} & \multirow[b]{2}{*}{$17^{\circ} 55^{\prime} 25.87^{\prime \prime}$} & \multirow[b]{2}{*}{1.8} & \multirow[b]{2}{*}{ sand ridge } & 1.451 & 1.212 & -0.258 & 1.650 \\
\hline & & & & & medium sand & poorly sorted & $\begin{array}{c}\text { coarse } \\
\text { skewed }\end{array}$ & $\begin{array}{c}\text { very } \\
\text { leptokurtic }\end{array}$ \\
\hline \multirow[b]{2}{*}{ B5 } & & & & & 0.963 & 0.989 & -0.188 & 1.106 \\
\hline & $40^{\circ} 10^{\prime} 03.00^{\prime \prime}$ & $17^{\circ} 56^{\prime} 51.17^{\prime \prime}$ & 2.2 & sand ridge & coarse sand & moderately sorted & $\begin{array}{c}\text { coarse } \\
\text { skewed }\end{array}$ & mesokurtic \\
\hline
\end{tabular}

In particular, Sample A1 refers to present dune deposit, Sample A2 to backshore beach deposit, and Sample A3 to shoreface deposit. All samples are totally comprised of sandy fractions; dune and beach sediments (Samples A1 and A2) show a mean size of 1.345 phi (medium sand) whereas the shoreface sample (A3) is slightly coarser $(\mathrm{Mz}=1.069$, medium sand). Sediments covering the submerged platform placed at about $4 \mathrm{~m}$ of depth at La Strea are made of very coarse sands (Sample $\mathrm{A} 4, \mathrm{Mz}=-0.199)$ and include a small gravelly fraction (9.5\%).

Four samples were collected at surveyed profiles about $1 \mathrm{~m}$ below the surface, in correspondence with the coastal sand ridge top (Samples B1, B2, B3 and B5 in Table 1 and Figure 7). These samples show variable mean sizes, from very coarse sand (Sample B2, Mz $=-0.148$ ), to coarse sand (Sample $\mathrm{B} 5, \mathrm{Mz}=0.963$ ) and medium sand (Sample B1, Mz = 1.145; Sample B3, Mz = 1.451), and almost all them include a gravelly fraction (from about $5 \%$ to over $20 \%$ ). Sorting values mark a clear difference between beach sediments and sand ridge sediments. The former, in fact, range between 0.642 and $0.710 \mathrm{phi}$ (moderately well sorted to moderately sorted sands, respectively); Sample A4 shows a sorting value of 0.864 phi (moderately sorted sands). Samples from the sand ridge show a worse sorting overall, with values between 0.840 and 1.430 phi (from moderately to poorly sorted sands). As for the other granulometric parameters, the skewness values reveal that most samples from the sandy ridge (B2, B3, B5) are coarse skewed, as well as Samples A2 and A3 from the present-day shoreface. A symmetrical grain size distribution marks, instead, Samples A1, A4 and B1. Kurtosis varies from platykurtic (Samples A3 and B1) to mesokurtic (Sample B5) and leptokurtic (Samples A1, A2, A4 and B2). Sample B3 is very leptokurtic.

The morphoscopic analysis revealed that all samples are mainly made of bioclasts and rare lithoclasts. In particular, beach samples (A1, A2, A3 and A4) are made of translucent, subspherical grains showing a very smooth surface. Observations of the faunal assemblages showed the occurrence of rare worn benthonic foraminifera (Ammonia beccarii, Elphidium crispum, Quinqueloculina sp., Peneroplis 
pertusus and Peneroplis planatus); they are associated with the occurrence of Posidonia oceanica meadows that, at present, locally taper the seabed between 18 and $25 \mathrm{~m}$ of depth. Sample A4 also contains abundant B. latreillei and a minor amount of $M$. neritoides, Mitrella sp., Alvania sp., Gibberula sp. and Tellina donacina; these are mostly herbivorous mollusks living in shallow coastal waters.

Samples from the sandy ridge (B1, B2, B3 and B5) are made of slightly opaque grains with different shapes (from tabular to low or medium sphericity) and various degrees of rounding (from sub-rounded to sub-angular). The microfaunal assemblage is similar to that observed in the present-day shoreface, i.e., represented by worn benthic foraminifera (Peneroplis pertusus, Peneroplis planatus, Elphidium crispum) and some miliolidae, in particular Quinqueloculina sp. The macrofauna comprises rare specimens of Columbella sp., Bittium latreillei, Vermetids or Serpulids, Gastropods and Echinods fragments. Both faunal assemblages can be related to shallow-water coastal environments (including rocky sea bottom) colonized by Posidonia oceanica.

\subsection{The GPR Survey}

A further investigation of the internal structure of the sand ridge was performed by means of GPR surveys along Profile S1 (La Strea site, Figure 9a) and Profile S5 (L'Arenile site, Figure 9b). In the latter site, observations from the top of the coastal sand ridge down to bedrock were previously carried out in a dug trench. Here, the bedrock was reached at about $1.8 \mathrm{~m}$ from the ground surface; it is covered by a decametric layer of dark reddish soil. Above, the detritic deposit appears massive and neither main discontinuities nor distinctive layers could be detected inside it.

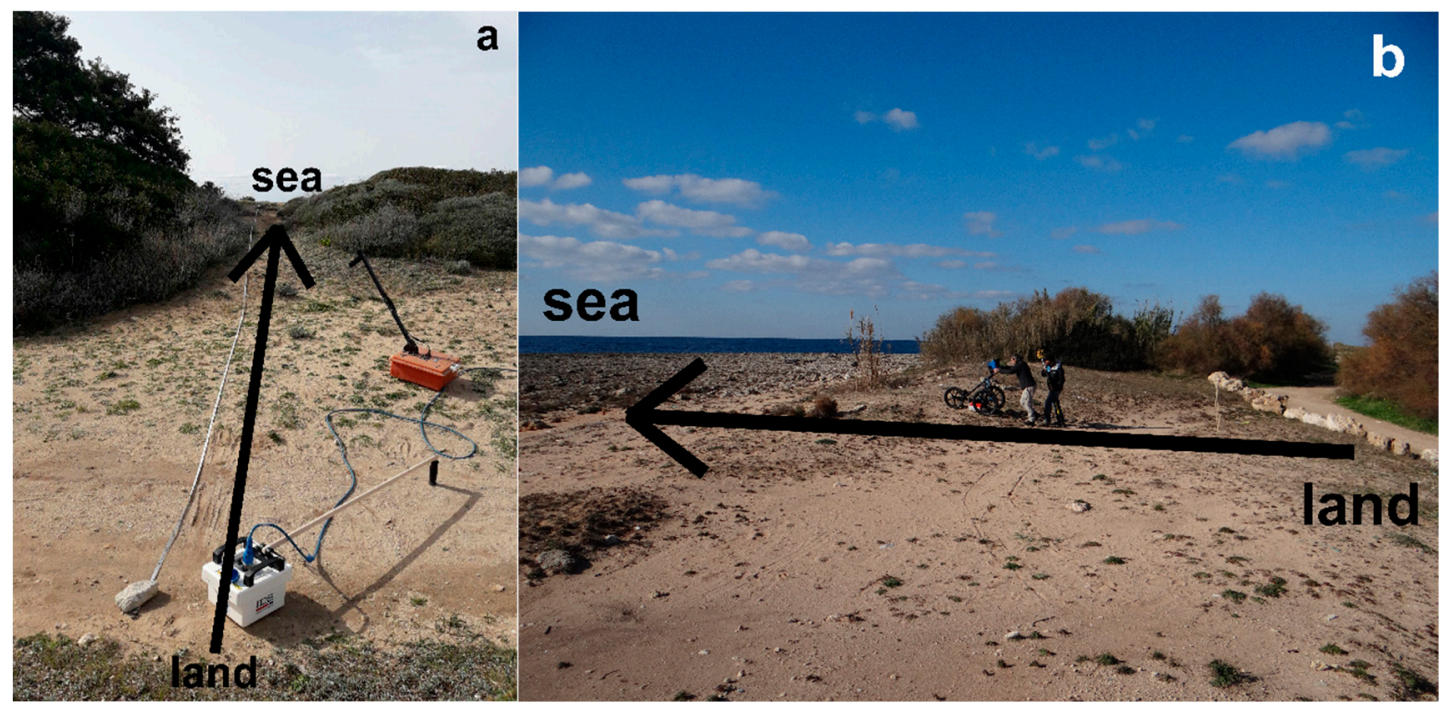

Figure 9. (a,b) - Location of GPR surveys carried out at Profile S1 (La Strea site) (left) and at Profile S5 (L'Arenile site) (right). See Figure 5 for the location.

GPR surveys allow the detection of local bedrock and soil cover (Figures 10 and 11); both levels, in fact, determine a rough GPR signal due to vertical change in EM rock properties. In particular, at Profile S5, a major discontinuity is recognizable between the Mesozoic limestones (Level 2 in Figure 11) and the soil cover (Level 3 in Figure 11) whereas at Profile S1 a thin layer of Pleistocene calcarenites is recognizable (Level 2A in Figure 10), interposed between the limestone bedrock and soil (Levels 2 and 3 , respectively). 


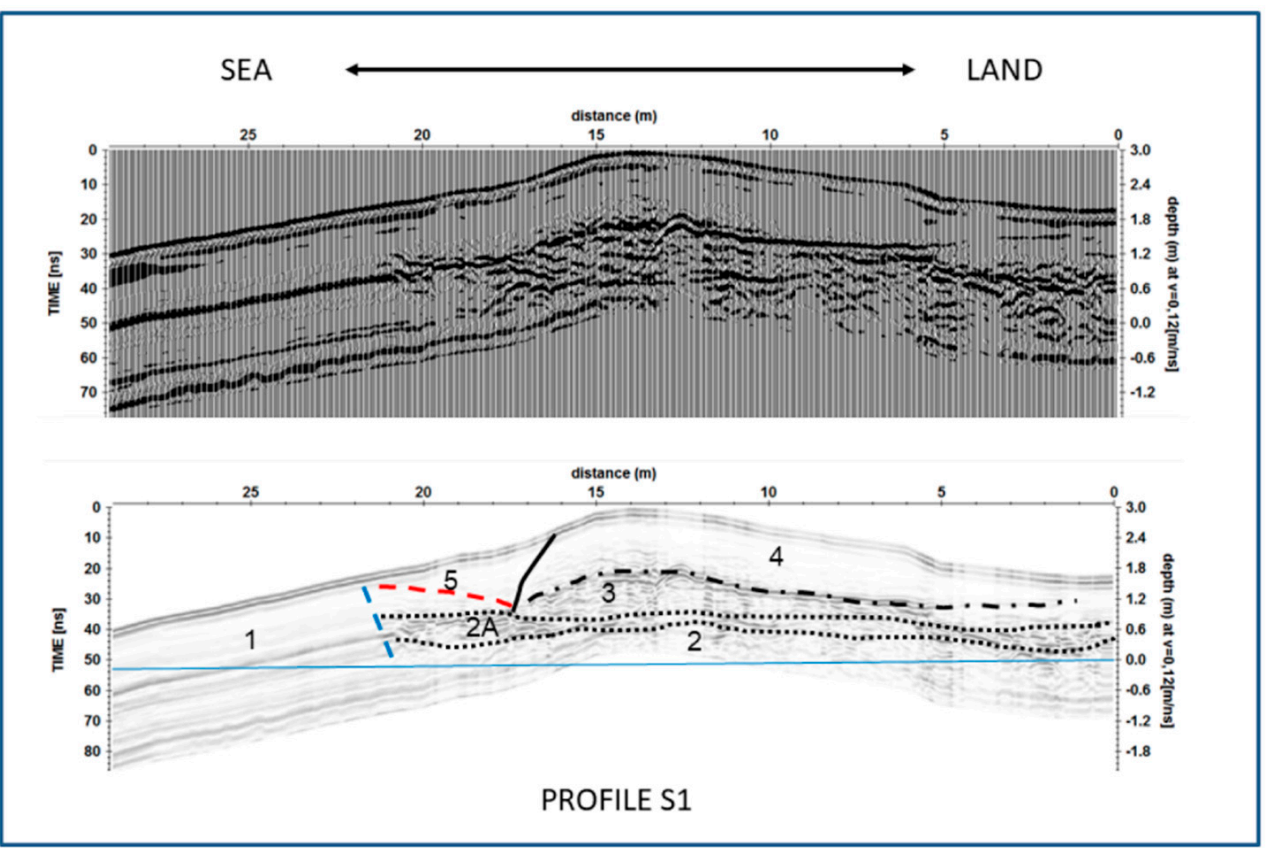

Figure 10. The GPR section (upper) performed at Profile S1 (La Strea site) and its interpretation (lower). The section is shown in wiggle traces. Legend: 1 -saturated zone; 2-bedrock (Mesozoic limestone); 2A-bedrock (Pleistocene calcarenites); 3-soil; 4-sand ridge deposits; 5-storm wave berm. The blue dashed line divides the saturated from the unsaturated zone, while the red dashed one outlines the landward-sloping lamination of a storm wave berm. The blue horizontal line is the position of mean sea level.

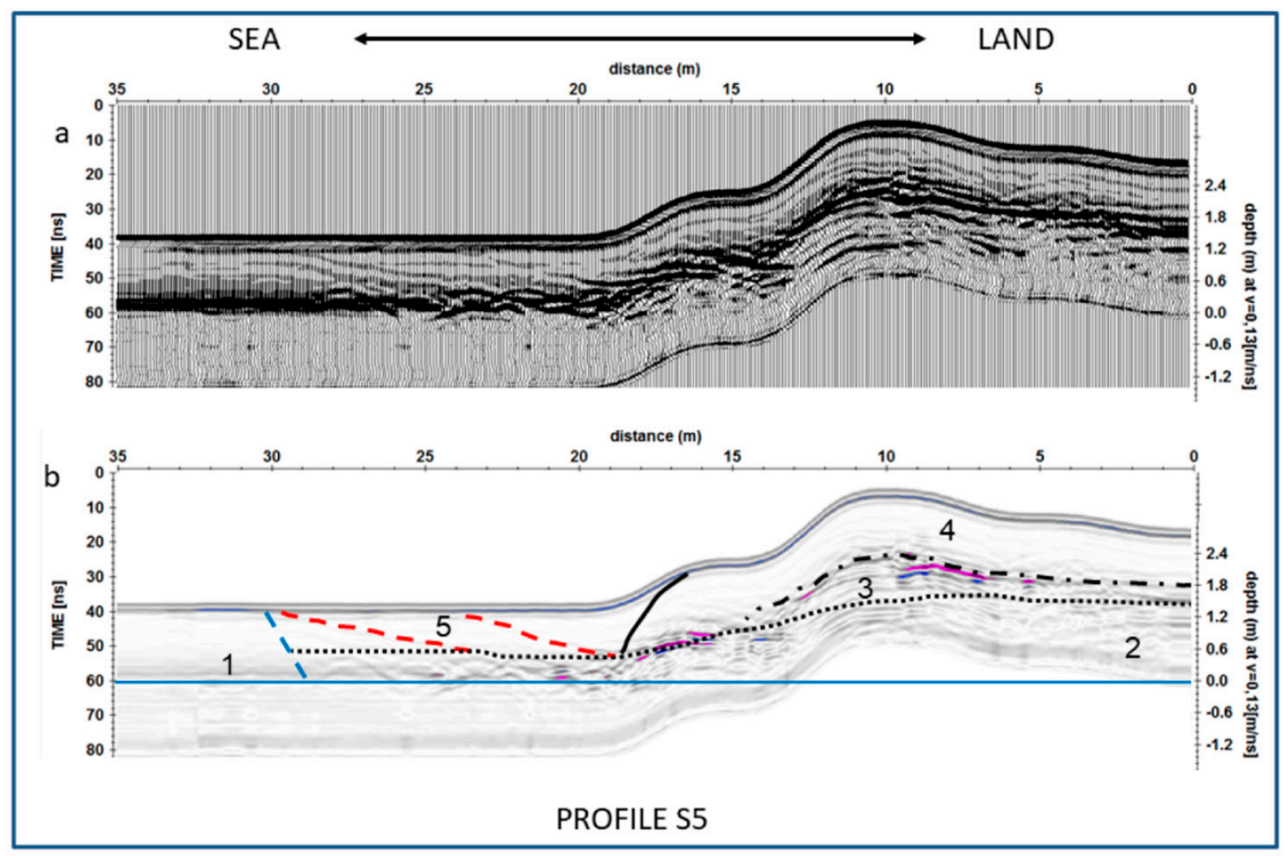

Figure 11. The GPR section (upper) carried out at Profile S5 (L'Arenile site) and its interpretation (lower). The section is shown in wiggle traces. Legend: 1 -saturated zone; 2 -bedrock (Pleistocene calcarenites); 3-soil; 4-sand ridge deposits; 5-storm wave berm. The blue dashed line divides the saturated from the unsaturated zone while the red dashed one outlines the landward-sloping lamination of a storm wave berm. The blue horizontal line is the position of mean sea level. 
The uppermost level (Level 4 in Figures 10 and 11), corresponding to the deposits of the studied sand ridge, appears homogeneous since no significant discontinuities can be detected inside it. In particular, both profiles show that the seaward foot of the sand ridge is marked out by few short surfaces gently sloping landward (red dashed line in Figures 10 and 11); they are interpreted as the landward slope of a berm (Level 5) formed during extreme sea storm events.

\subsection{The AMS Radiocarbon Age Determinations}

A number of AMS radiocarbon age determinations were performed to obtain some chronological constraints for the coastal sand ridge deposition. In detail, six samples have been collected at Profile S1 (La Strea locality, Porto Cesareo) at about 1 meter below the top of the ridge. Two of them (Samples ST1 and ST2, Table 2) are specimens of Columbella rustica, whereas the other four are Conus ventricosus (Samples ST3, ST4, ST5 and ST6, Table 2). Further AMS age determinations on samples collected from the same coastal sand ridge are available from the literature; in fact, [27] report age data yielded by two samples of Columbella rustica (Samples BPS 1A and BPS 1B) at the S2 profile. Moreover, other AMS age determinations were performed on biogenic material collected at boulder accumulations in different places along the Ionian coast of southern Apulia, i.e., Baia d'Argento, Punta Prosciutto and Torre Castiglione [7,12,27] (Table 2).

Table 2. AMS radiocarbon age determinations performed on samples collected at Profile S1 of the sand ridge (ST1-ST6) and reported in literature for samples coming from Profile S2 (BPS 1A and BPS 1B) along with chronological data related to large-size boulder accumulations detected along several sites along the Ionian coast of Apulia (Punta Prosciutto, Torre Castiglione: Samples TC1 and TC2, Baia d'Argento: Samples LTL1178A, LTL1179A and LTL2209A) [7,12,27]. See Figure 2 for site locations.

\begin{tabular}{|c|c|c|c|c|c|c|c|c|c|c|}
\hline SAMPLE & Locality & $\begin{array}{c}\text { Long. } \\
\text { (WGS84) }\end{array}$ & $\begin{array}{c}\text { Lat. } \\
\text { (WGS84) }\end{array}$ & CEDAD ID & Specimen & $\begin{array}{l}\text { Radiocarbon } \\
\text { Age }(B P)\left({ }^{*}\right)\end{array}$ & $\delta^{13} \mathcal{C}(\% o)$ & $\Delta \mathrm{R}$ & $\begin{array}{c}\text { CALIBRATED AGE } \\
(2 \sigma)\end{array}$ & References \\
\hline ST1 & La Strea & $17^{\circ} 54^{\prime} 04^{\prime \prime}$ & $40^{\circ} 14^{\prime} 42^{\prime \prime}$ & LTL18141A & $\begin{array}{c}\text { Columbella } \\
\text { rustica }\end{array}$ & $1419 \pm 45$ & $-4.3 \pm 0.6$ & $58 \pm 15$ & $\begin{array}{l}929 \mathrm{AD}(95.4 \%) \\
1168 \mathrm{AD}\end{array}$ & this paper \\
\hline ST2 & La Strea & $17^{\circ} 54^{\prime} 04^{\prime \prime}$ & $40^{\circ} 14^{\prime} 42^{\prime \prime}$ & LTL18142A & $\begin{array}{c}\text { Columbella } \\
\text { rustica }\end{array}$ & $685 \pm 45$ & $-1.7 \pm 0.3$ & $58 \pm 15$ & $\begin{array}{c}\text { 1549AD (95.4\%) } \\
1815 \mathrm{AD}\end{array}$ & this paper \\
\hline ST3 & La Strea & $17^{\circ} 54^{\prime} 04^{\prime \prime}$ & $40^{\circ} 14^{\prime} 42^{\prime \prime}$ & LTL18143A & $\begin{array}{c}\text { Conus } \\
\text { ventricosus }\end{array}$ & $828 \pm 45$ & $1.9 \pm 0.1$ & $58 \pm 15$ & $\begin{array}{c}1460 \mathrm{AD}(95.4 \%) \\
\text { 1648AD }\end{array}$ & this paper \\
\hline ST4 & La Strea & $17^{\circ} 54^{\prime} 04^{\prime \prime}$ & $40^{\circ} 14^{\prime} 42^{\prime \prime}$ & LTL18144A & $\begin{array}{c}\text { Conus } \\
\text { ventricosus }\end{array}$ & $1287 \pm 45$ & $-0.5 \pm 0.3$ & $58 \pm 15$ & $\begin{array}{c}\text { 1062AD }(95.4 \%) \\
1275 \mathrm{AD}\end{array}$ & this paper \\
\hline ST5 & La Strea & $17^{\circ} 54^{\prime} 04^{\prime \prime}$ & $40^{\circ} 14^{\prime} 42^{\prime \prime}$ & LTL18145A & $\begin{array}{c}\text { Conus } \\
\text { ventricosus }\end{array}$ & $617 \pm 45$ & $-3.0 \pm 0.2$ & $58 \pm 15$ & $\begin{array}{c}\text { 1660AD (92.7\%) } \\
\text { 1896AD }\end{array}$ & this paper \\
\hline ST6 & La Strea & $17^{\circ} 54^{\prime} 04^{\prime \prime}$ & $40^{\circ} 14^{\prime} 42^{\prime \prime}$ & LTL18146A & $\begin{array}{c}\text { Conus } \\
\text { ventricosus }\end{array}$ & $563 \pm 45$ & $-0.2 \pm 0.3$ & $58 \pm 15$ & $\begin{array}{c}\text { 1707AD }(95.4 \%) \\
\text { 1950AD }\end{array}$ & this paper \\
\hline $\begin{array}{c}\text { Punta } \\
\text { Prosciutto }\end{array}$ & $\begin{array}{c}\text { Punta } \\
\text { Prosciutto }\end{array}$ & $17^{\circ} 45^{\prime} 52^{\prime \prime}$ & $40^{\circ} 17^{\prime} 28^{\prime \prime}$ & - & Lithophaga & $700 \pm 64$ & 0.5 & $58 \pm 15$ & $\begin{array}{c}\text { 1502AD (95.4\%) } \\
1836 \mathrm{AD}\end{array}$ & $\begin{array}{l}\text { Mastronuzzi et al., } \\
2000\end{array}$ \\
\hline BPS 1A & La Strea & $17^{\circ} 54^{\prime} 23^{\prime \prime}$ & $40^{\circ} 14^{\prime} 22^{\prime \prime}$ & - & $\begin{array}{c}\text { Columbella } \\
\text { rustica }\end{array}$ & $721 \pm 35$ & -2.7 & $58 \pm 15$ & $\begin{array}{l}\text { 1530AD (95.4\%) } \\
\text { 1705AD }\end{array}$ & $\begin{array}{c}\text { Mastronuzzi et al., } \\
2008\end{array}$ \\
\hline BPS 1B & La Strea & $17^{\circ} 54^{\prime} 23^{\prime \prime}$ & $40^{\circ} 14^{\prime} 22^{\prime \prime}$ & - & $\begin{array}{c}\text { Columbella } \\
\text { rustica }\end{array}$ & $761 \pm 45$ & -2.7 & $58 \pm 15$ & $\begin{array}{c}\text { 1499AD (95.4\%) } \\
\text { 1685AD }\end{array}$ & $\begin{array}{l}\text { Mastronuzzi et al., } \\
2008\end{array}$ \\
\hline TC1 & $\begin{array}{c}\text { Torre } \\
\text { Castiglione }\end{array}$ & $17^{\circ} 49^{\prime} 10^{\prime \prime}$ & $40^{\circ} 17^{\prime} 12^{\prime \prime}$ & - & Vermetids & $1242 \pm 40$ & 0.5 & $58 \pm 15$ & $\begin{array}{c}\text { 1117AD (95.4\%) } \\
\text { 1303AD }\end{array}$ & $\begin{array}{c}\text { Mastronuzzi et al., } \\
2008\end{array}$ \\
\hline TC2 & $\begin{array}{c}\text { Torre } \\
\text { Castiglione }\end{array}$ & $17^{\circ} 49^{\prime} 10^{\prime \prime}$ & $40^{\circ} 17^{\prime} 12^{\prime \prime}$ & - & Vermetids & $608 \pm 40$ & 1.9 & $58 \pm 15$ & $\begin{array}{c}\text { 1670AD }(92.8 \%) \\
1895 \mathrm{AD} \\
1940 \mathrm{AD}(2.6 \%) 1950 \mathrm{AD}\end{array}$ & $\begin{array}{l}\text { Mastronuzzi et al., } \\
2008\end{array}$ \\
\hline - & $\begin{array}{c}\text { Baia } \\
\mathrm{d}^{\prime} \text { Argento }\end{array}$ & $17^{\circ} 19^{\prime} 41^{\prime \prime}$ & $40^{\circ} 21^{\prime} 43^{\prime \prime}$ & LTL1178A & Vermetids & $413 \pm 40$ & 0.5 & $58 \pm 15$ & $\begin{array}{c}\text { 1842AD (95.4\%) } \\
\text { 1950AD }\end{array}$ & $\begin{array}{l}\text { Mastronuzzi \& } \\
\text { Pignatelli, } 2012\end{array}$ \\
\hline - & $\begin{array}{c}\text { Baia } \\
d^{\prime} \text { Argento }\end{array}$ & $17^{\circ} 19^{\prime} 41^{\prime \prime}$ & $40^{\circ} 21^{\prime} 43^{\prime \prime}$ & LTL1179A & Vermetids & $489 \pm 60$ & 1.3 & $58 \pm 15$ & $\begin{array}{c}\text { 1724AD (95.4\%) } \\
\text { 1950AD }\end{array}$ & $\begin{array}{l}\text { Mastronuzzi \& } \\
\text { Pignatelli, } 2012\end{array}$ \\
\hline - & $\begin{array}{c}\text { Baia } \\
\mathrm{d}^{\prime} \text { Argento }\end{array}$ & $17^{\circ} 19^{\prime} 41^{\prime \prime}$ & $40^{\circ} 21^{\prime} 43^{\prime \prime}$ & LTL2209A & Vermetids & $426 \pm 35$ & 0.4 & $58 \pm 15$ & $\begin{array}{c}\text { 1845AD }(95.4 \%) \\
1950 \mathrm{AD}\end{array}$ & $\begin{array}{l}\text { Mastronuzzi \& } \\
\text { Pignatelli, } 2012\end{array}$ \\
\hline
\end{tabular}

Taking into account a $2 \sigma$ confidence interval, the calibrated ages obtained in this work span from 929-1168 AD (Sample ST1) to 1707-1950 AD (Sample ST6) (Table 2). Then, chronological data would indicate a recent origin for the coastal sand ridge, less than ten centuries ago; in particular, four age determinations (ST2, ST3, ST5, ST6) cluster around 1600-1900 AD. These results are in agreement with chronological data from the literature that mostly gather in the same chronological interval (Figure 12), while three age determinations (ST1, ST4 and TC1) yielded a possible age around 1100 AD. 


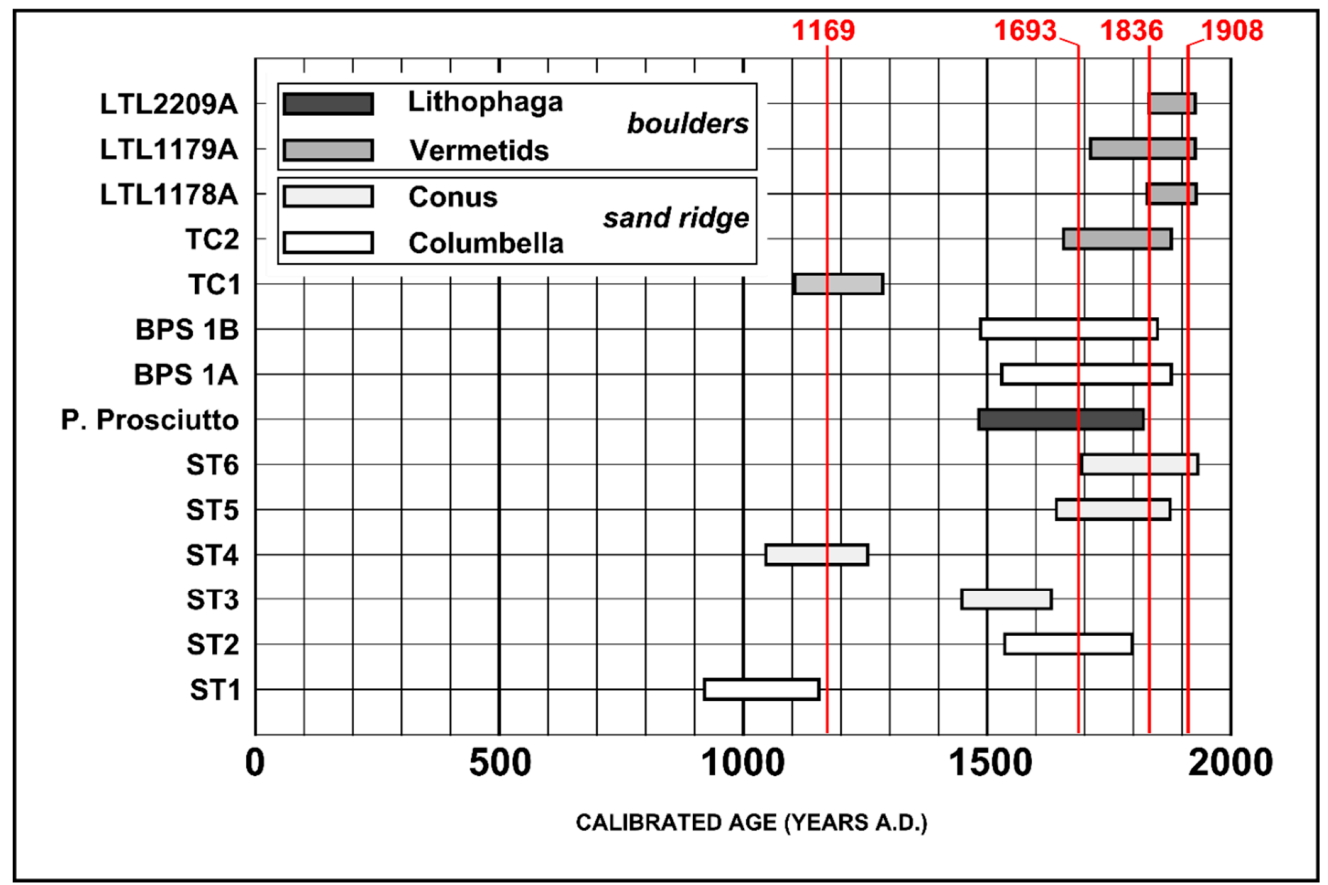

Figure 12. AMS radiocarbon age of samples collected at Profile S1 of the sand ridge (from ST1 to ST6) compared with chronological data available in the literature for the same site or surrounding areas (see Table 2). The dates of tsunami events occurring in the Ionian Sea since 1000 A.D. are also reported (red lines; from [2]).

\section{Discussion}

\subsection{Coastal Sand Ridges as Tsunami Markers}

Long tracts of the Ionian coast of Southern Apulia, stretching from Porto Cesareo village to the L'Arenile site, are characterized by an up to 100-m-wide rocky coastal platform which is backed by a coastal sand ridge. The latter is about $40-60 \mathrm{~m}$ wide and elevated up to about $4 \mathrm{~m}$ above mean sea level. Large-size boulders also rest on the rocky platform and at the Torre Inserraglio site (Profile S3) are clearly connected to the sand ridge.

The morphology and the position of the coastal sand ridge resemble a relic coastal dune belt. However, multi-disciplinary analysis carried out on ridge deposits clearly indicates that it lacks the main features of coastal dunes, i.e., the occurrence of sorted medium fine sands and high-angle cross-stratification. In fact, the studied coastal sand ridge is made of poorly sorted, coarse sands and does not show internal structures; micro and macro-faunal assemblages clearly indicate that sediments come from nearby shallow waters.

The integrated data-set suggests that the studied coastal sand ridge can be referred to the action of a single catastrophic event such as a tsunami, able to carve and transport large size boulders as well as to mix up very coarse bioclastic sands covering the present-day submerged platform and storm beach deposits, presently occurring in patches at the low-elevated rocky coastal platform. The stripping of the platform surface was eventually accomplished by the deposition inland of a coastal sand ridge directly on the reddish soil level, which locally covers the bedrock.

Some authors [28] define these kind of sediments, marked by a chaotic mixture and minimal sorting, as "dump deposits" which point to a very short time span for related depositional/reworking processes. Congruent with this rapid event is the deposition of broken fragile particles (e.g., foraminifera, shells). Moreover, according to various authors [29], extensive field study of paleo-tsunami deposits in the Mediterranean, the Caribbean and the Bahamas proves that the occurrence of "bimodal deposits", i.e., a mixture of fine and coarse grain sizes, is a common characteristic of tsunami deposits which 
have interacted with rocky environments like cliffs, coastal platforms or coral reefs during the impact. The grain size distribution may vary from a few, small, floating coarse particles in a sandy matrix to boulder size dominating the accumulation, enclosed in thin veneers of sand. The sediment structure is, in the majority of cases, chaotic, but occasionally coarser fragments may be enriched at the base of the units, presumably representing a base surge during the tsunami.

In the Mediterranean area, sand ridges similar to that one surveyed along the Ionian coast of southern Apulia occur in the southeastern part of Mallorca island (Cabo de ses Salines) [29,30]. Densely vegetated, dune-like deposits with a height of about $15 \mathrm{~m}$ have been detected there, notwithstanding the lack of beaches as source areas for sandy deposits, as is the case in our study. Sand is the dominant sediment on the upper part of these deposits, but occasionally small boulders and shell fragments can be found incorporated within or on top of the sandy deposits. On the lower slope, as well as in the supratidal zone, boulders (about $20 \mathrm{t}$ weigh) have been accumulated. A detailed investigation of the boulder ridges revealed that they would represent paleo-tsunami deposits, which could be dated to $500 \mathrm{BP}$ and $1400 \mathrm{BP}$ by radiocarbon dating [30]. Comparable deposits can be also found at Cabo de Trafalgar in southern Atlantic Spain [31], possibly related to the 1755 Lisboa tsunami, and along the west coast of the Akamas peninsula on Cyprus island [32], where they have been referred by the authors to a tsunami dating back to $1650-1700 \mathrm{AD}$.

In Southern Apulia, previous studies $[7,8,12,13]$ associated the occurrence of large-size boulders accumulated at the coast with the effects of tsunami impacts during the last five centuries. Taking into account the Torre Squillace large-size boulder features, [33] calculated that the largest boulder detected in the area was dislodged from the cliff edge by an impacting tsunami wave with a minimum height of $4.94 \mathrm{~m}$. The estimated maximum inland water penetration was of about $140 \mathrm{~m}$ and would be marked in the field by an erosive step occurring at the landward limit of the soil stripped belt. At Torre Castiglione, there is morphological evidence of the association between coastal sand ridges and boulder accumulations [27].

\subsection{Tracking down the Generative Event}

Although AMS radiocarbon analyses of recent marine samples do not allow very precise age determinations, especially when adopting the calibration method, which implies a wide error range, the available chronological data would indicate that boulder accumulations detected along this coast and the surveyed coastal sand ridge can be related to the same time frame. The AMS age data set shows that most chronological data are younger than five centuries old; only a few age determinations yielded an older age.

An attempt to identify the possible tsunami event responsible for boulder accumulations and coastal sand ridge deposition can be supported by the following considerations:

1. The tsunami generative mechanism should occur in an area close to the Ionian coast of Southern Apulia since tsunami propagation into the Mediterranean Basin is hampered by its complex bathymetry and coastline shape [34]. Moreover, the particular shape of the Taranto Gulf allows tsunami propagation from the Ionian Greek side to be excluded. Model simulations performed by [3] confirm, in fact, that tsunamis produced by seismogenetic structures placed along the western Greek coast do not significantly affect the Ionian coast of Southern Apulia.

2. The imbrication of boulders indicates a S-SW direction of tsunami approach to the coast [7].

3. The tsunami should have been strong enough to produce morphological effects on the coast. According to the Sieberg-Ambraseys intensity scale [35], strong damage can be observed due to events starting from intensity 4.

4. If a relatively recent age is assumed for the tsunami event (last ten centuries), this should be included in the available catalogues, since it is most unlikely that such a strong event should have been unnoticed in recent historical times. 
The Euro-Mediterranean Tsunami Catalogue [2] reports 11 events affecting eastern Sicily and the Ionian west coast, all generated by strong earthquakes which occurred in the last ten centuries (Table 3). Taking into account an intensity threshold of at least 4, only four events could have struck the Ionian coast of Southern Apulia with enough power to produce the observed morphological effects. These events occurred in 1169, 1693, 1836 and 1908 (in bold in Table 3).

Table 3. List of tsunamis which occurred in the Ionian Sea (Italian area) during the last ten centuries from [2]. Distance is measured in $\mathrm{km}$ in a direct line from the epicenter to the Ionian coast of Southern Apulia. Reliability ranges from 0 ("very improbable tsunami") to 4 ("definite tsunami"). Associated cause: ER (submarine earthquake), EA (earthquake in land), VA (volcano-related), SLS (submarine landslide). Intensity is according to the Sieberg-Ambraseys scale [31]. In particular, intensity 3 represents the threshold for which tsunamis are capable of producing some damage to boats and light coastal structures, while strong damage can be observed starting from intensity 4 [35].

\begin{tabular}{|c|c|c|c|c|c|c|c|c|c|c|c|c|}
\hline Year & Month & Day & Hour & Minutes & Source & Long & Lat & Distance & Short description & Rel & Cause & Int \\
\hline 1169 & 2 & 4 & 7 & - & Eastern Sicily & 15.030 & 37.320 & 400 & $\begin{array}{c}\text { Flood and destruction } \\
\text { at Messina }\end{array}$ & 4 & EA & 4 \\
\hline 1329 & 6 & 28 & - & - & Eastern Sicily & 15.000 & 37.730 & 375 & Boats carried to the sea & 2 & VA & 3 \\
\hline 1693 & 1 & 9 & 21 & - & Eastern Sicily & 15.035 & 37.141 & 400 & $\begin{array}{c}\text { Anomalous sea } \\
\text { movement }\end{array}$ & 2 & ER & 2 \\
\hline 1693 & 11 & 11 & 3 & 30 & Eastern Sicily & 15.013 & 37.140 & 400 & $\begin{array}{l}\text { Large sea withdrawal } \\
\text { and flooding }\end{array}$ & 4 & ER & 5 \\
\hline 1783 & 25 & 8 & - & - & Ionian Calabria & 15.970 & 38.297 & 160 & $\begin{array}{l}\text { At Capo Rizzuto } \\
\text { inundations }\end{array}$ & 2 & EA & 3 \\
\hline 1784 & 1 & 7 & - & - & Ionian Calabria & - & - & 250 & Sea flooding at Roccella & 4 & ER & 3 \\
\hline 1818 & 2 & 20 & 18 & 15 & Eastern Sicily & 15.140 & 37.603 & 375 & $\begin{array}{c}\text { Withdrawal/inundation } \\
\text { at Catania }\end{array}$ & 4 & EA & 2 \\
\hline 1832 & 3 & 8 & 18 & 30 & Ionian Calabria & 16.919 & 39.079 & 160 & $\begin{array}{c}\text { Sea flooding at } \\
\text { Magliacane Crotone }\end{array}$ & 4 & EA & 3 \\
\hline 1836 & 4 & 25 & 0 & 20 & Ionian Calabria & 16.737 & 39.567 & 120 & $\begin{array}{l}\text { Sea retreat/flooding. } \\
\text { Boats damaged }\end{array}$ & 4 & EA & 4 \\
\hline 1907 & 10 & 23 & 20 & 28 & Ionian Calabria & 15.985 & 38.086 & 300 & $\begin{array}{c}\text { Sea flooding at Capo } \\
\text { Bruzzano }\end{array}$ & 4 & EA & 3 \\
\hline 1908 & 12 & 28 & 4 & 20 & $\begin{array}{l}\text { Eastern } \\
\text { SicilySouthern } \\
\text { Calabria }\end{array}$ & 15.687 & 38.146 & 310 & $\begin{array}{c}\text { Destructions, } \\
\text { hundreds of victims }\end{array}$ & 4 & $\begin{array}{c}\text { ER } \\
\text { or } \\
\text { SLS }\end{array}$ & 6 \\
\hline
\end{tabular}

In particular, the 1908 Messina earthquake $(\mathrm{Mw}=7.1)$ was the most catastrophic event that occurred in the 20th century in Italy. This earthquake produced a catastrophic tsunami that struck the southern Calabrian and the eastern Sicilian coasts causing further damage and casualties [36,37]. The tsunami flooded a coastal belt up to 250-270 $\mathrm{m}$ wide in north-eastern Sicily [36,38]. The tsunami wave effects were also observed along the Tyrrhenian coast of Sicily and in the Sicily Channel as far as the Malta Islands [36,39]. Despite the relevant intensity of the 1908 tsunami (grade 6 according to the Sieberg-Ambraseys scale), effects on the Ionian coast of Southern Apulia are not reported [2].

The 1169 earthquake, with an estimated magnitude 6.6, struck the eastern Sicilian coast and part of southern Calabria, causing considerable damage in Val di Noto (south-eastern Sicily), Piana di Catania (central part of eastern Sicily) and Val Demone (north-eastern Sicily) [40]. According to a chronicle of the 13th century (Chronaca Pisana, 1722), "catania civitas a terremotu subversa est usque ad fundamenta, et ex ea nec masculus nec femina evasit" (the city of Catania was raised to the ground by the earthquake and not one man nor woman remained). Several permanent phenomena on the ground were observed in a wide area from the Ionian coast to Piazza Armerina. This earthquake generated a tsunami that affected the city of Messina and the Simeto river near Catania and destroyed the village of Casal Simeto [41].

The same area was struck by another catastrophic tsunami in the 1693, when two big earthquakes (Maw $=6.2$, January 9, and Maw $=7.4$, January 11) caused destruction and heavy damage in most of Eastern Sicily [42]. After the main shock of January 11, whose epicenter is placed more than $370 \mathrm{~km}$ from the Ionian coast of Southern Apulia, a large tsunami (grade 5 on the Sieberg-Ambraseys scale) affected the whole eastern coast of Sicily, the Aeolian Islands and Mazzarelli, the old harbor of Marina 
di Ragusa, and the Southern Sicilian coast. The known length of inundated shoreline was about $230 \mathrm{~km}$ [38]. Model simulations performed by [43] clearly show that this tsunami would not have produced significant sea level change at Taranto, about $80 \mathrm{~km}$ to the NW of the studied area (Figure 2). Research at Augusta Bay (eastern Sicily) carried out by [44] found geological evidence for these three main historical tsunamis in the inland and/or offshore record.

The 25 April 1836 tsunami was generated by a strong earthquake $(\mathrm{Mw}=6.2)$ with its epicenter placed in the coastal area of Rossano Calabro [45], only $120 \mathrm{~km}$ to the southwest of the Ionian coast of Apulia (Figure 1b). Eyewitness accounts indicate that the tsunami flooded the Rossano coastal plain up to $70 \mathrm{~m}$ inland, producing a strong morphological change of the beach profile [46-49]. Unfortunately, chronicles about this event related to the Ionian coast of Apulia have not been found, except a report written by [50] almost a century later. This could be most likely related to the lack of coastal settlements from Taranto to Gallipoli at that time. Some useful historical information could be provided by possible damage to the numerous coastal towers built along the coast in the second half of 16th century, but they were already abandoned in the 19th century. Previous authors [12] linked the boulder accumulations at the Baia d'Argento site, placed about $50 \mathrm{~km}$ to the NNW of the studied area, to this tsunami event.

Overall, data on historical tsunamis would refer the deposition of the coastal sand ridge detected along the Ionian coast of Southern Apulia to the tsunami generated as the consequence of the 25 April 1836 earthquake which occurred at the northern Calabrian coast. However, the radiocarbon age would also suggest the reworking of sediments, possibly transported on the rocky platform, during the 1169 and 1694 tsunami events.

\section{Conclusions}

Multi-disciplinary analysis of a coastal sand ridge detected along the rocky coast between La Strea site (Porto Cesareo municipality) and L'Arenile site (Nardò municipality) was performed. The sand ridge resembles a coastal dune belt placed at the back of a bare, low-elevated rocky platform; however, analysis reveals that it is constituted by poorly sorted coarse sands without sedimentary structures, in some places in connection with large-size boulders. These features suggest that the studied sand ridge was most likely produced by a tsunami event.

Taking into account the chronological constraints supplied by AMS age determination and the available tsunami catalogues, it is possible to relate the sand ridge formation to the 25 April 1836 tsunami, which was produced by a strong earthquake with its epicenter near Rossano, at the Ionian coast of Calabria, only $120 \mathrm{~km}$ to the southwest of studied area. This event was likely able to rework very coarse bioclastic sands from the submerged platform and mix them with medium-sand deposits due to extreme storm accumulation as well as with older sediments possibly transported towards the coast by the 1169 and 1693 tsunamis.

The 1836 tsunami was also responsible for the carving, transport and accumulation of large-size boulders from sub and supratidal areas of rocky platforms. Boulders have been found sparsely in lines of imbricated elements or in large accumulations at several sites along the Ionian coast of Southern Apulia.

The results of this research stress once again the relevant tsunami hazard which affects the coast of Southern Apulia, a densely urbanized and populated area, especially during summer, and point to the need for civil protection plans aiming to mitigate tsunami risk.

Author Contributions: Data curation: P.S., L.C., S.N., G.Q., C.R., A.V. and G.M. Funding acquisition: G.M.; Investigation: P.S., L.C., P.F., S.M., S.N., G.Q., A.V. and G.M. Writing-original draft: P.S., S.M., S.N., G.Q., C.R. and G.M. Writing-review and editing: P.S. and C.R. All authors have read and agreed to the published version of the manuscript.

Funding: This research was funded by the Flagship Project RITMARE—Italian Research for the Sea—coordinated by the Italian National Research Council and funded by the Italian Ministry of Education, University and Research within the National Research Program 2011-2013 (Resp. Research Unit 02 Action 2 “Deterministic assessment of tsunami hazard on the coast of Southern Italy": G. Mastronuzzi). APC was funded by MIUR - RIBA, resp. P. Sansò. 
Acknowledgments: This paper is an Italian contribution to the to the project IGCP 639 International Geological Correlation Program "Sea-level change from minutes to millennia" by UNESCO-IUGS (Project Leaders: S. Engelhart, G. Hoffmann, F. Yu and A. Rosentau).We thank Stefano Claudio Vaiani and Daniele Scarponi of the BIGEA Department, Bologna University, for helping with the morphoscopic and paleoecological analysis of samples.

Conflicts of Interest: The authors declare no conflict of interest.

\section{References}

1. Vilibić, I.; Šepić, J. Global mapping of nonseismic sea level oscillations at tsunami timescales. Sci. Rep. 2017, 7, 40818. [CrossRef] [PubMed]

2. Maramai, A.; Brizuela, B.; Graziani, L. The Euro-Mediterranean Tsunami Catalogue. Ann. Geoph. 2014, 57, 4.

3. Tiberti, M.M.; Lorito, S.; Basili, R.; Kastelic, V.; Piatanesi, A.; Valensise, G. Scenarios of earthquake-generated tsunamis for the Italian coast of the Adriatic Sea. Pure Appl. Geophys. 2008, 165, 2117-2142. [CrossRef]

4. Scardino, G.; Piscitelli, A.; Milella, M.; Sansò, P.; Mastronuzzi, G. Tsunami fingerprints along the Mediterranean coasts. Rend. Lincei Sci. Fis. Nat. 2020. [CrossRef]

5. Slejko, D.; Camassi, R.; Cecic, I.; Herak, D.; Herak, M.; Kociu, S.; Kouskouna, V.; Lapajine, J.; Makropoulos, K.; Meletti, C.; et al. Seismic hazard assessment for Adria. Ann. Geofis. 1999, 42, 1085-1107.

6. Ferranti, L.; Burrato, P.; Pepe, F.; Santoro, E.; Mazzella, M.E.; Morelli, D.; Passaro, S.; Vannucci, G. An active oblique contractional belt at the transition between the Southern Apennines and Calabrian Arc: The Amendolara Ridge, Ionian Sea, Italy. Tectonics 2014, 33, 2169-2194. [CrossRef]

7. Mastronuzzi, G.; Sansò, P. Boulders transport by catastrophic waves along the Ionian coast of Apulia (Southern Italy). Mar. Geol. 2000, 170, 93-103. [CrossRef]

8. Mastronuzzi, G.; Sanso', P. Large Boulder Accumulations by Extreme Waves along the Adriatic Coast of southern Apulia (Italy). Quat. Int. 2004, 120, 173-184. [CrossRef]

9. Mastronuzzi, G.; Sanso', P. Evidenze geomorfologiche di maremoti storici lungo la costa salentina (Puglia meridionale). Quaderni de l'Idomeneo 2012, 13, 203-219.

10. Gianfreda, F.; Mastronuzzi, G.; Sanso', P. Impact of historical tsunamis on a sandy coastal barrier: An example from the northern Gargano coast, southern Italy. Nat. Haz. Earth Syst. Sci. 2001, 1, 1-6. [CrossRef]

11. Mastronuzzi, G.; Pignatelli, C.; Sansò, P.; Selleri, G. Boulder accumulations produced by the 20th February 1743 tsunami along the coast of southeastern Salento (Apulia region, Italy). Mar. Geol. 2007, 242, 191-205. [CrossRef]

12. Mastronuzzi, G.; Pignatelli, C. The boulders berm of Punta Saguerra (Taranto, Italy): A morphological imprint of the Rossano Calabro tsunami of April 24, 1836? Earth Planets Space 2012, 64, 829-842. [CrossRef]

13. Mastronuzzi, G.; Pignatelli, C.; Sansò, P. Boulder Fields: A Valuable Morphological Indicator of Paleotsunami in the Mediterranean Sea. Zeit. Geomorph. NF Suppl. Bd. 2006, 146, 173-194.

14. Mastronuzzi, G.; Palmentola, G.; Ricchetti, G. Aspetti dell'evoluzione olocenica della costa pugliese. Mem. Soc. Geol. Ital. 1989, 42, 287-300.

15. Ferranti, L.; Antonioli, F.; Mauz, B.; Amorosi, A.; Dai Prà, G.; Mastronuzzi, G.; Monaco, C.; Orrù, P.; Pappalardo, M.; Radtke, U.; et al. Markers of the last interglacial sea level high stand along the coast of Italy: Tectonic implications. Quart. Intern. 2006, 145-146, 30-54. [CrossRef]

16. Mastronuzzi, G.; Quinif, Y.; Sansò, P.; Selleri, G. Middle-Late Pleistocene polycyclic evolution of a geologically stable coastal area (southern Apulia, Italy). Geomorphology 2007, 86, 393-408. [CrossRef]

17. Hearty, P.J.; Dai Pra, G. The age and stratigraphy of middle Pleistocene and younger deposits along the Gulf of Taranto (southeast Italy). J. Coast. Res. 1992, 8, 882-905.

18. Blott, S.J.; Pye, K. Gradistat: A Grain Size Distribution and Statistics Package for the Analysis of Unconsolidated Sediments. Earth Surf. Process. Landforms 2001, 26, 1237-1248. [CrossRef]

19. Folk, R.L.; Ward, W.C. A Study in the Significance of Grain-Size Parameters. J. Sed. Petrol. 1957, $27,3-26$. [CrossRef]

20. Jol, H.M. Ground Penetrating Radar: Theory and Applications; Elsevier: Amsterdam, The Netherlands, 2008.

21. Annan, A.P. Ground Penetrating Radar Principles, Procedures \& Applications Subsurface Imaging Solutions; Sensors \& Software Inc.: Mississauga, ON, Canada, 2003.

22. Guillemoteau, J.; Bano, M.; Dujardin, J.R. Influence of grain size, shape and compaction on georadar waves: Examples of aeolian dunes. Geophys. J. Int. 2012, 190, 1455-1463. [CrossRef] 
23. Neal, A. Ground-penetrating radar and its use in sedimentology: Principles, problems and progress. Earth Sci. Rev. 2004, 66, 261-330. [CrossRef]

24. Bailey, S.; Bristow, C.S. The structure of coastal dunes: Observations from ground penetrating radar (GPR) surveys. In Proceedings of the SPIE-The International Society for Optical Engineering. Eighth International Conference on Ground Penetrating Radar, Gold Coast, Australia, 27 April 2000.

25. Calcagnile, L.; Maruccio, L.; Scrimieri, L.; delle Side, D.; Braione, E.; D’Elia, M.; Quarta, G. Development and application of facilities at the Centre for Applied Physics, Dating and Diagnostics (CEDAD) at the University of Salento during the last 15 years. Nucl. Instrum. Methods Phys. Res. Sect. B Beam Interact. Mater. Atoms 2019, 456, 252-256. [CrossRef]

26. Reimer, P.J. IntCal13 and Marine13 Radiocarbon Age Calibration Curves 0-50,000 Years cal BP. Radiocarbon 2013, 55, 1869-1887. [CrossRef]

27. Mastronuzzi, G.; Sansò, P.; Bruckner, H.; Pignatelli, C.; Vott, A.; Caputo, R.; Coppola, D.; Di Bucci, D.; Fracassi, U.; May, S.M.; et al. Paleotsunami imprints along the coast of the central Mediterranean sea. In Proceedings of the 2nd International Tsunami Field Symposium, Lefkada, Grecia, 21-27 September 2003.

28. Bryant, E. Tsunami. In The Underrated Hazard; Cambridge University Press: Cambridge, UK, 2001.

29. Scheffers, A.; Kelletat, D. Bimodal Tsunami Deposits; a Neglected Feature in Paleo-Tsunami Research. In Proceedings of the 22nd Annual Conference Die Küsten Union Deutschland, Warnemünde, Germany, 28-30 April 2004; pp. 67-75.

30. Bartel, P.; Kelletat, D. Erster Nachweis holozäner Tsunamis im westlichen Mittelmeergebiet (Mallorca, Spanien) mit einem Vergleich von Tsunami- und Sturmwellenwirkungen auf Festge-steinsküsten. Berichte Forschungs-und Technologiezentrum Westküste der Universität Kiel 2003, 28, 93-107.

31. Whelan, F.; Kelletat, D. Boulder deposits on the southern Spanish Atlantic coast: Possible evidence for the 1755 AD Lisbon tsunami? Sci. Tsunami Hazards 2005, 23, 25-38.

32. Kelletat, D.; Schellmann, G. Tsunamis in Cyprus: Field Evidences and 14C-Dating Results. Zeit. Geomorph. NF 2002, 46, 19-34. [CrossRef]

33. Pignatelli, C.; Sansò, P.; Mastronuzzi, G. Evaluation of tsunami flooding using geomorphologic evidence. Mar. Geol. 2009, 260, 6-18. [CrossRef]

34. Soloviev, S.L.; Solovieva, O.N.; Go, G.N.; Kim, K.S.; Shchetnikov, N.A. Tsunamis in the Mediterranean Sea 2000 B.C-2000 A.D. In Advances in Natural and Technological Hazards Research; Springer: Berlin/Heidelberg, Germany, 2000.

35. Ambraseys, N. Data for the investigation of the seismic sea waves in the Eastern Mediterranean. B. Seismol. Soc. Am. 1962, 52, 895-913.

36. Platania, G. Il maremoto dello Stretto di Messina del 28 dicembre 1908. Boll. Soc. Sismol. Ital. 1909, 13, 369-458. (In Italian)

37. Sabatini, V. Il Maremoto nell'attuale Disastro. Lega Navale 1909, 5, 4-5. (In Italian)

38. Gerardi, F.; Barbano, M.S.; De Martini, P.M.; Pantosti, D. Discrimination of Tsunami Sources (Earthquake versus Landslide) on the basis of Historical Data in Eastern Sicily and Southern Calabria. Bull. Seismol. Soc. Am. 2008, 98, 2795-2805. [CrossRef]

39. Baratta, M. La Catastrofe Sismica Calabro-Messinese del 28 Dicembre 1908, Relazione alla Società Geografica Italiana; Arnaldo Forni: Bologna, Italy, 1910.

40. Barbano, M.S.; Rigano, R.; Cosentino, M.; Lombardo, G. Seismic history and hazard in some localitiesof south-eastern Sicily. Boll. Geof. Teor. Appl. 2001, 42, 107-120.

41. Lombardo, G. The Catania earthquake of February 4, 1169. In Atlas of Isoseismal Maps of Italian Earthquake; Postpischl, D., Ed.; PFG-CNR: Bologna, Italy, 1985.

42. De Martini, P.M.; Barbano, M.S.; Pantosti, D.; Smedile, A.; Pirrotta, C.; Del Carlo, P.; Pinzi, P. Geological evidence for paleotsunamis along eastern Sicily (Italy): An overview. Nat. Haz. Earth Syst. Sci. 2012, 12, 2569-2580. [CrossRef]

43. Gutscher, M.A.; Roger, J.; Baptista, J.M.; Miranda, J.M.; Tinti, S. Source of the 1693 Catania earthquake and tsunami (southern Italy): New evidence from tsunami modeling of a locked subduction fault plane. Geoph. Res. Lett. 2006, 33, L08309. [CrossRef]

44. Smedile, A.; De Martini, P.M.; Pantosti, D. Combining inland and offshore paleotsunamis evidence:the Augusta Bay (eastern Sicily, Italy) case study. Nat. Hazards Earth Syst. Sci. 2012, 12, 2557-2567. [CrossRef] 
45. Galli, P.; Spina, V.; Ilardo, I.; Naso, G. Evidence of active tectonics in southern Italy: The Rossano fault (Calabria). In Recent Progress on Earthquake Geology; Guarnieri, P., Ed.; Nova Science Publishers Inc.: New York, NY, USA, 2010.

46. Romano, M. Relazione del Sindaco Michele Romano al Sottintendente del distretto sul terremoto del 25 April 1836. In Deliberazioni del Decurionato (1834-1836); Archivio Storico del Comune di Rossano: Cosenza, Italy, 1836.

47. Rossi, A.A. De' tremuoti nella Calabria Citeriore l'anno 1836. Ann. Civ. Regno Due Sicilie 1836, 12, 12-34. (In Italian)

48. Rossi, A.A. Storia dei Tremuoti di Calabria Negli Anni 1835 e 1836; R. de Stefano: Napoli, Italy, 1837. (In Italian)

49. De Rosis, L. Cenno Storico Della Città di Rossano e Delle Sue Nobili Famiglie; Stamperia Nicola Mosca: Napoli, Italy, 1838.

50. Baffi, E. Saggio di effemeridi tarantine. Boll. Prov. Ion. (Taras) 1929, IV, 47-61.

(C) 2020 by the authors. Licensee MDPI, Basel, Switzerland. This article is an open access article distributed under the terms and conditions of the Creative Commons Attribution (CC BY) license (http://creativecommons.org/licenses/by/4.0/). 